\title{
A Comprehensive Review of Problem-based Learning in the Iranian Nursing Education
}

\author{
Fatemeh Hajibabaee $^{1}$, Hadis Ashrafizadeh ${ }^{2}$
}

\begin{abstract}
Background \& Aims: Evaluation and application of novel educational approaches are essential for improving educational programs. Problem-based learning (BPL) is a new education approach that is based on the principles of using problems as a starting point for acquiring and combining new knowledge. Problem-based skills are not taught in a codified and organized way in Iran. Research shows that while reviews have been conducted on PBL in other fields, no review has been carried out to in the nursing field in the country. Meanwhile, there is lack of consensus over the advantages and disadvantages of traditional and PBL teaching methods. Given the importance of applicability of PBL in nursing education, the present study aimed to review studies performed on the effect of PBL on nursing students' abilities in the country, determine nursing students' viewpoint about PBL and factors affecting PBL, compare PBL training with other education methods, and explain nursing students' experience of PBL in Iran.
\end{abstract}

Materials \& Methods: This comprehensive review study was performed to review all Farsi articles related to PBL in the nursing field. We searched Iranian databases such as Scientific Information Database (SID), Magiran, Iran Medex, and Iranian Research Institute for Information Science and Technology using the keywords of learning, training, education, problem-solving, PBL, problem-centered, and nursing. The timeline evaluated was April 2001-January 2018. The inclusion criteria were the Farsi language of articles and using PBL in nursing education. On the other hand, the exclusion criterion was a lack of access to the full text of articles. There were no restrictions on the entry of studies based on the type of studies performed. The full text of the articles was studied and related data were extracted based on research objectives using a pre-developed checklist that included variables such as sample size, as well as location, time, type, and results of studies.

Results: The initial search of keywords and a combination of the words using AND led to the extraction of 115 Farsi articles. A primary assessment of articles' titles and abstracts in the screening stage resulted in the elimination of unrelated articles and duplicates. In total, 45 articles were entered the selection phase, and 70 articles were removed from the research due to lack of meeting the inclusion criteria, duplication, presentation of abstracts on conferences, and lack of access to the full text of the articles. Ultimately, 31 Farsi articles that were published in domestic research-scientific journals and their full text was available were selected. Most of the studies in this field were conducted by a quasi-experimental method (20 studies), seven by descriptive method, two by qualitative method, one by review method, and one by the clinical trial method. In addition, most studies were performed on BSc students and only one research included MSc nursing students. The studies reviewed in the present study were divided into several parts: 1) studies related to the effect of PBL on students' abilities, such as self-concept, emotional intelligence, self-efficacy, determination and problem-solving skills, anxiety, empathy, the vision of success, learning and decision-making techniques, spirituality and philosophical mentality, and logical, avoidant and dependent decision-making styles; 2) studies related to the assessment and comparison of PBL teaching method with other techniques; 3) studies related to the evaluation of nursing students' opinions about PBL training; 4) qualitative research, and 5) PBL and effective factors.

\footnotetext{
1. Assistant Professor, School of Nursing and Midwifery, Tehran University of Medical Sciences, Tehran, Iran

2. PhD Candidate in Nursing, Student Research Committee, School of Nursing and Midwifery, Ahvaz Jundishapur University of Medical Sciences. Ahvaz, Iran (Corresponding author) Tel: 00989335047127 ashrafizadeh.h1993@gmail.com
} 
Conclusion: Given the fact that most studies reviewed reported the effectiveness of PBL in training nurses and enabling students and its comprehensive use in educating nursing students, and since limited studies have shown contradictory results, it could be expressed that students participate in the teaching process when using active training methods (e.g., PBL), which increases in-depth learning and self-confidence of students. Overall, more indepth learning is extremely crucial for improving practical skills in clinical environments. In this regard, nursing schools can hold courses to familiarize and teach this type of teaching method to professors and inform them of the importance and benefits of this method to teach nursing students who will be working in clinical settings in the future. Students who are successful in their professional and clinical skills use creative and thoughtful strategies in dealing with problems. Usually, there are different levels of using PBL skills in educational environments. Since studies often indicate the superiority and positive effect of PBL methods over traditional teaching methods, it is expected that the method be used in the country's medical universities, especially nursing and midwifery schools with the support of officials and professors. It is suggested that comparative assessments be carried out in educational environments in the form of multi-year longitudinal studies to assess the effects of university education methods on the levels of these skills in students.

Keywords: Learning, Education, Problem-solving, Nursing, Comprehensive Review

\section{Conflict of Interest: No}

How to Cite: Hajibabaee F, Ashrafizadeh H. A Comprehensive Review of Problem-based Learning in the Iranian Nursing Education. Iran Journal of Nursing. 2019; 32(118):12-30.

Received: 4 March 2019

Accepted: 8 Jun 2019 


\title{
مرور جامع يادتيرى مبتنى بر حل مسأله در آموزش برستارى ايران
}

\author{
فاطمه حاجى بابايى'، حديث اشرفى زاده广
}

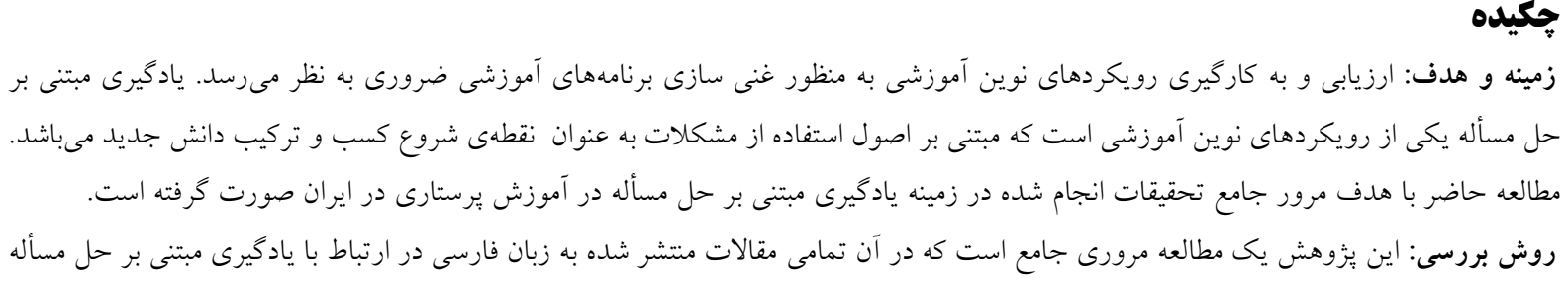

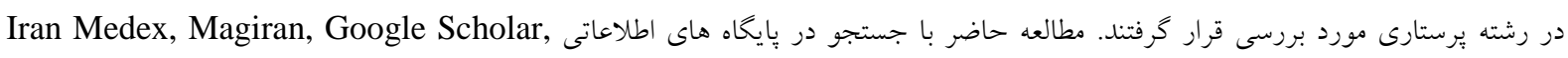
Iranian Research Institute for Information Science, Scientific Information Database

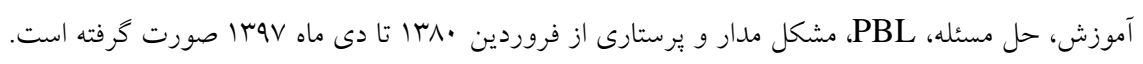

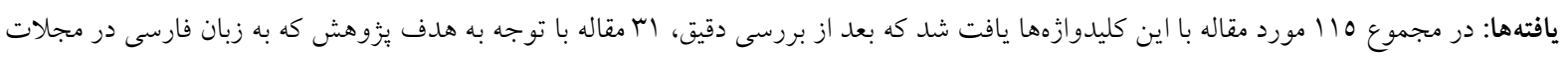

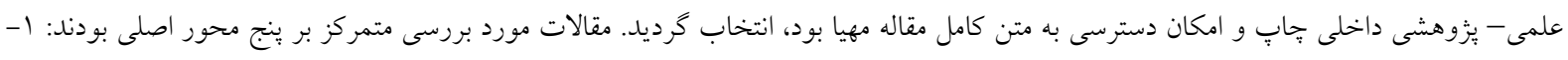

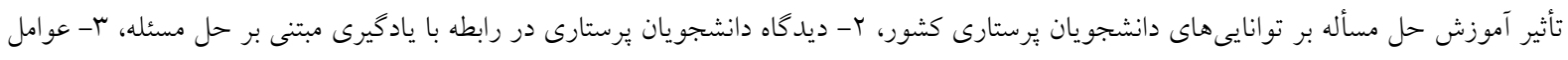

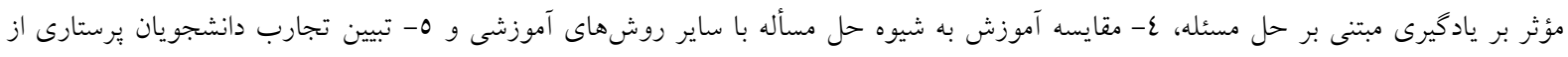

$$
\text { يادئيرى مبتنى بر حل مسئله. }
$$

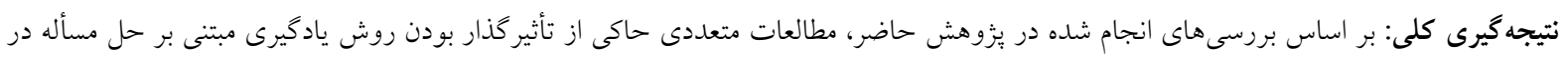

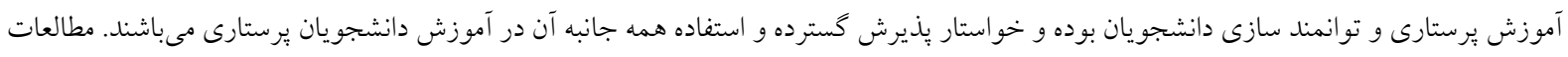

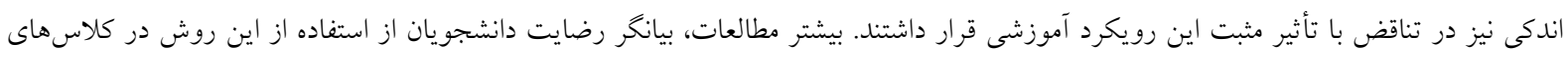

كليد وازهها: يادگيرى، آموزش، حل مسئله، برستارى، مرور جامع

تعارض منافع: ندارد

تاريخ دريافت: س

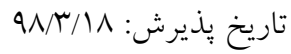

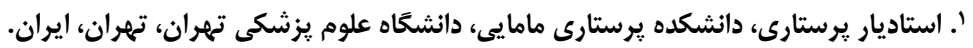

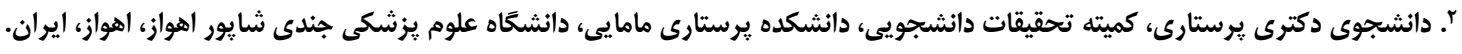


مجموعه گروهى و همجنين مهارتهايى جهت توسعه

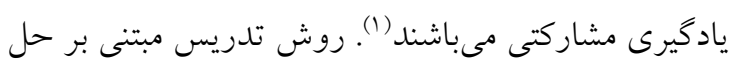

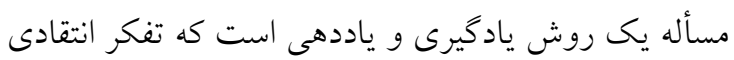

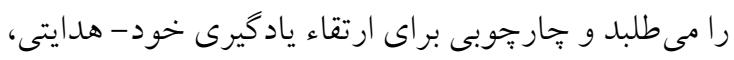

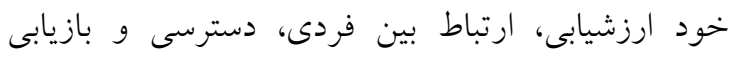

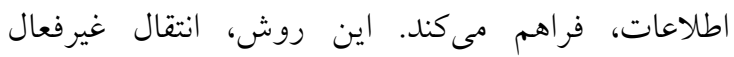

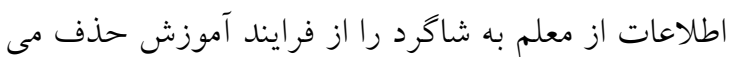
كند رويكرد PBL از روشهاى تسهيل كننده آموزش است كه

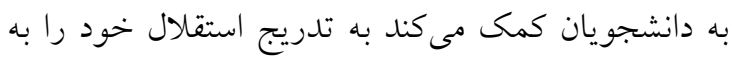

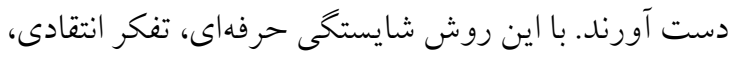
مهارتهاى ارتباطى، روابط بين فردى و خود ارزيابى

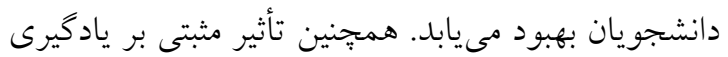

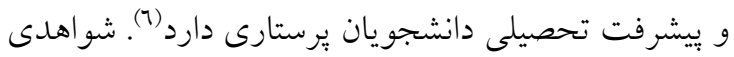

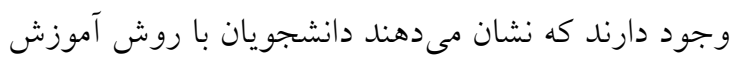
مبتنى بر حل مسأله بهتر مىتوانند دروس وِايه را بر بالين

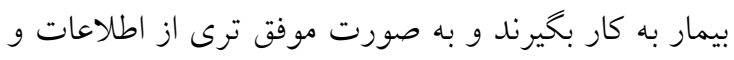

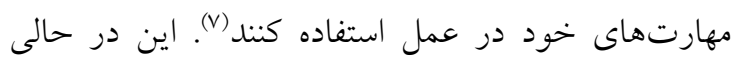

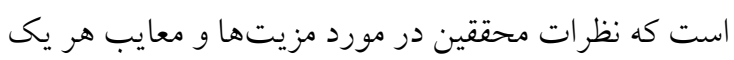

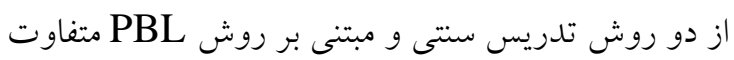

است.

يكى از مشكلاتى كه در آموزش به شيوه سنتى مطرح مى إنى

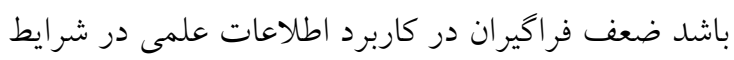
واقعى و در طى انجام وظايف حرفهاى مىباشد. فراگيران

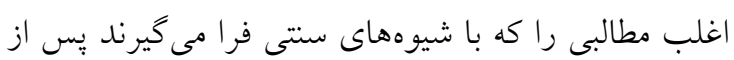

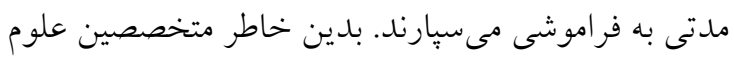

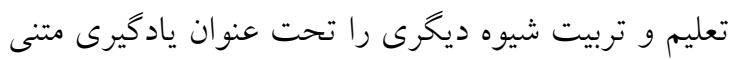
بر طرح مسأله مطرح ساختند كه در سالهاى اخير مورد استفاده بيشتر دانشخاهها در كشورهاى مختلف قرار گرفته

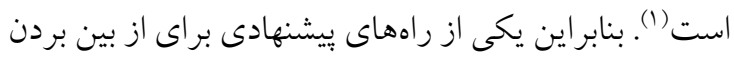

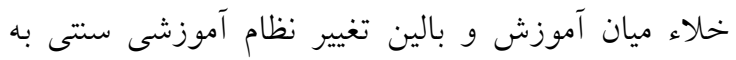

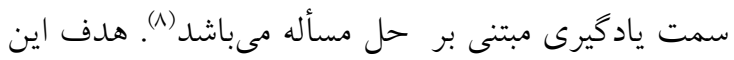

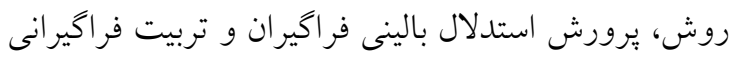

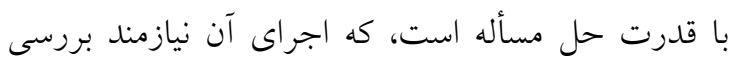

\section{مقدمه}

يادكيرى مبتنى بر حل مسأله Pablem Based ) PBL

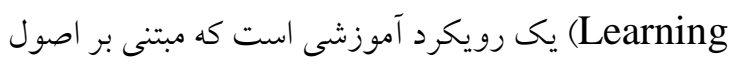

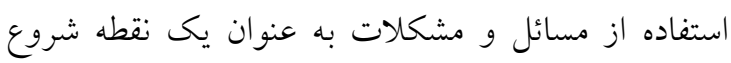

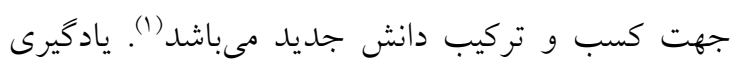

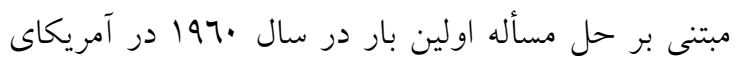
شمالى معرفى گرديد و در سال 1977 دانشخاه مكى ماستر

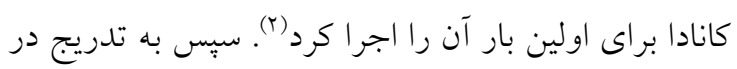

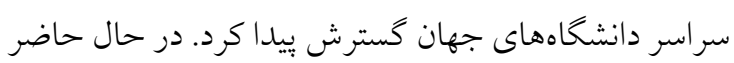

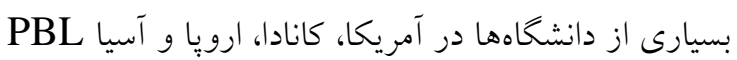

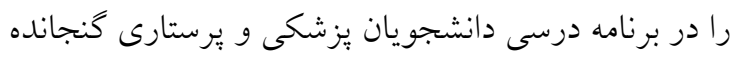

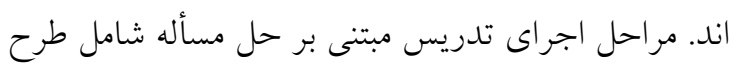

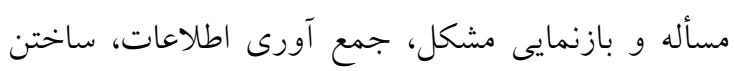

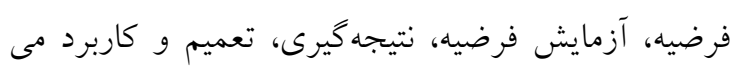

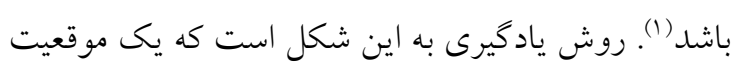

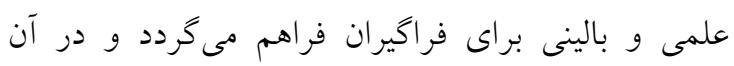

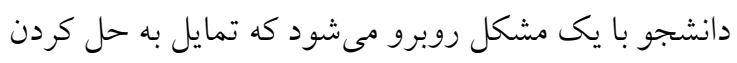

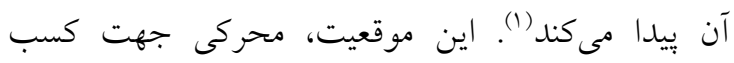

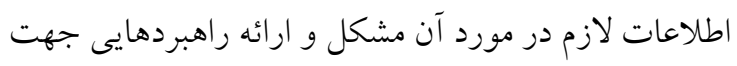
حل آن است (r). اين روش نوعى يادگيرى دانشجو محور است كه بر مو اجهه

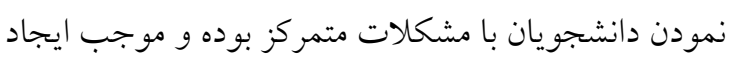
انخيزه و تحريك دانشجويان براى يادگيرى مى شودود.

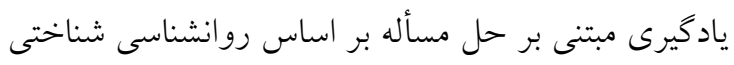

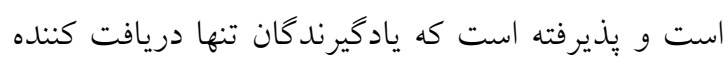

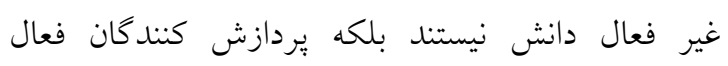

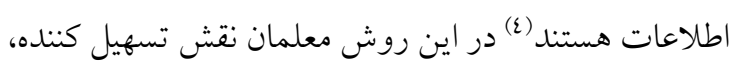
راهنمايى و هدايت فرايند يادكيرى را بر عهلده دارند.

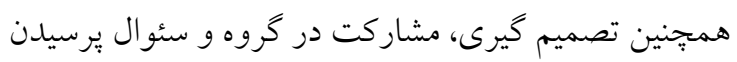

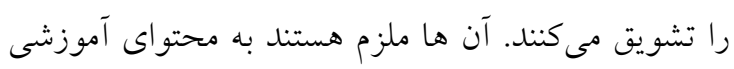
و شيوه آموزش تسلط داشته باشند. در مقابل، كروه

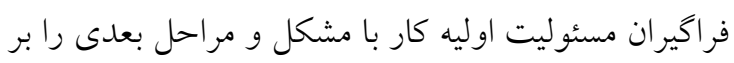

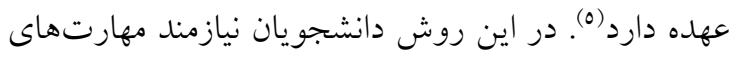
اعتماد, مسئوليت يذيرى، مراقبت و همدردى در يك 
مسأله در كشور ايران صورت كرفته است. با انجام اين

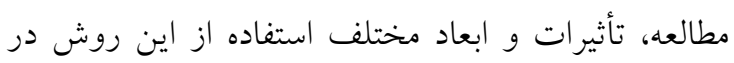
آموزش يرستارى و در بستر سيستم آموزش عالى كشور روشن مىشود كه مىتواند به عنوان راهنمايى براى اساتيد

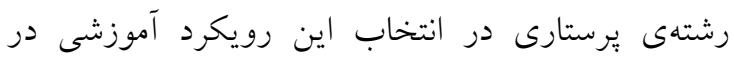

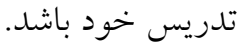

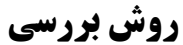

اين يُزوهش يكى مطالعه مرورى جامع است كه در آن تمامى مقالات متتشر شده به زبان فارسى در ارتباط با لمان يادگيرى مبتنى بر حل مسأله در رشته يرستارى مورد

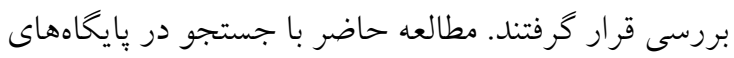
اطلاعاتى ايرانى از جمله Scientific Information بانك اطلاعات نشريات كشور (SID) Database و Iran Medex ،Google scholar ،Magiran يزوهشخاه علوم و فناورى اطلاعات ايران Iranian Research Institute for Information Science and Technology) آموزش، حل مسئله، PBL، مشكل مدار و پِرستارى از

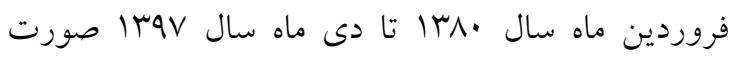
كرفته است. معيارهاى ورود مطالعات به اين بزورهش نحارش مقاله به زبان فارسى و استفاده از روش يادكيرى

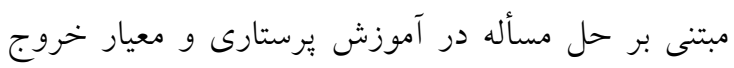
مطالعات دسترسى نداشتن به متن كامل مطالعات تعيين شد. لازم به ذكر است كه هيج نوع محدوديتى براى ورود مطالعات بر اساس نوع مطالعات انجام شده، وجود نداشت. متن كامل همه مقاله ها مطالعه شده و بادر نظر كرفتن هدف يُزوهش، دادههاى مرتبط استخراج شدند. در جستجوى

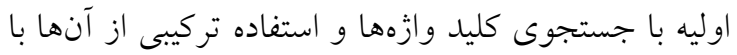
استفاده از كلمه AND مجموعاً 110 مقاله فارسى ييدا شد. در بررسى اوليه با بررسى عناوين و جكيده مقالات در

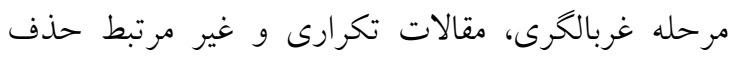

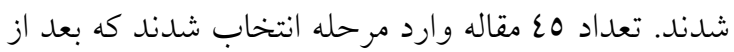

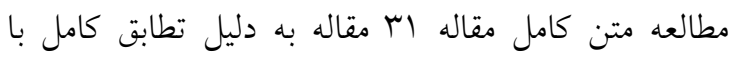

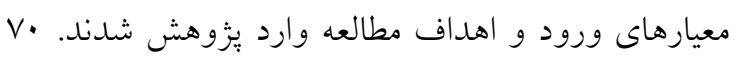

دقيق فرايند و برنامه ريزى معنىدار توسط اساتيد جهت توسعه سناريوهاى يادگيرى مىباشد (9).

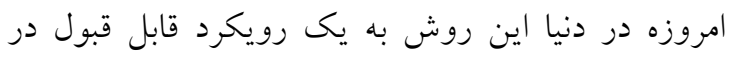

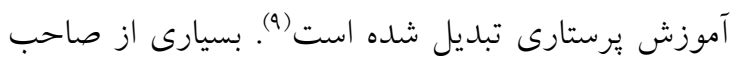

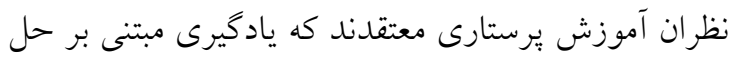

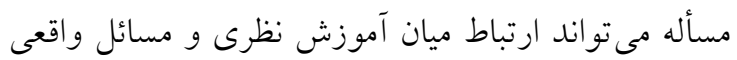

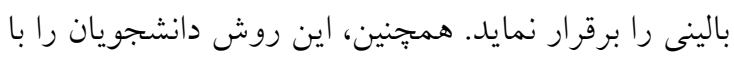

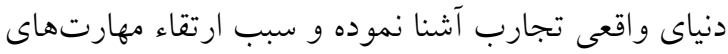

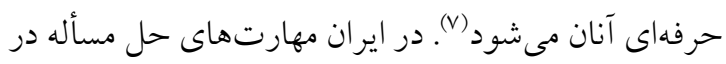
برنامهاى آموزشى دانشجويان يِرستارى به صورت مدون

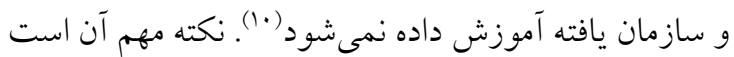
كه تغيير در راهبردهاى آموزش بدون تغيير در برنامه درسى

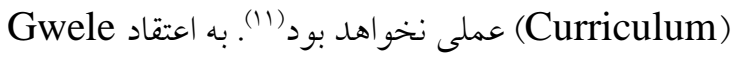

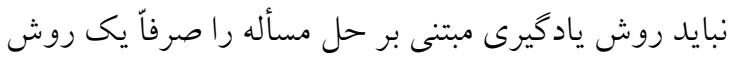

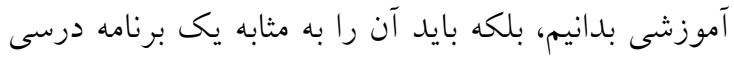

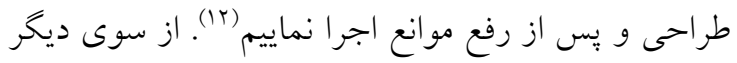

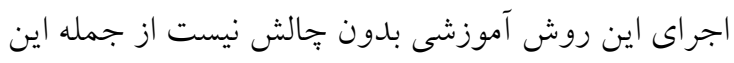

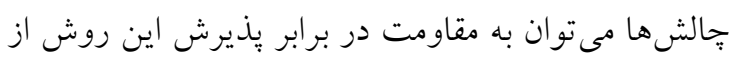

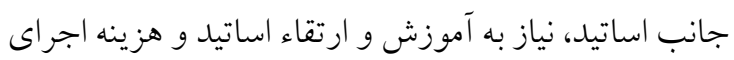

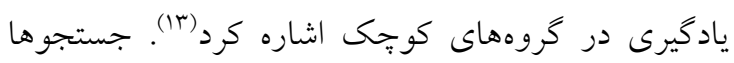

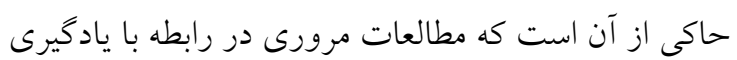

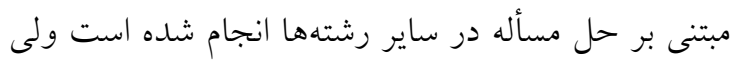
تاكنون مطالعهاى در اين زمينه در رشته يرستارى در كشور

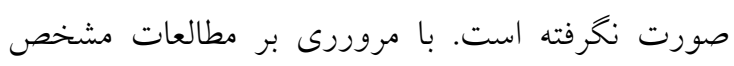

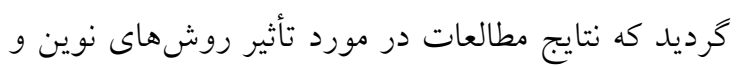
روشهاى سنتى آموزش در دروس برستارى با يكديخر

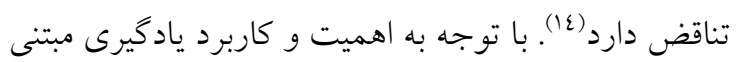

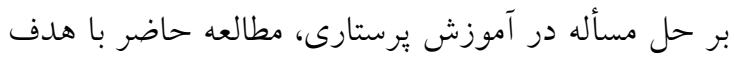
مرور تحقيقات انجام شده در زمينه تأثير آموزش حل مل مسأله بر توانايىهاى دانشجويان برستارى كشور، تعيين ديدگاه

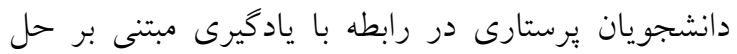

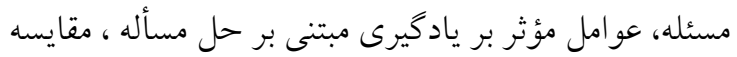

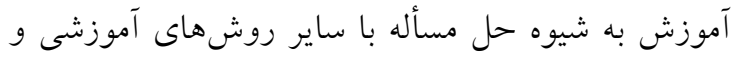

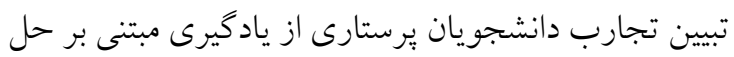


مقاله به دليل عدم تطابق با معيارهاى ورود، تكرارى بودن،

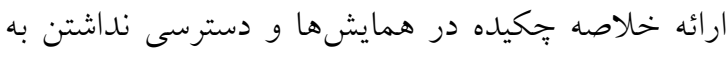

متن كامل مقاله از مطالعه حذف شدند. (شكل شماره ماند )

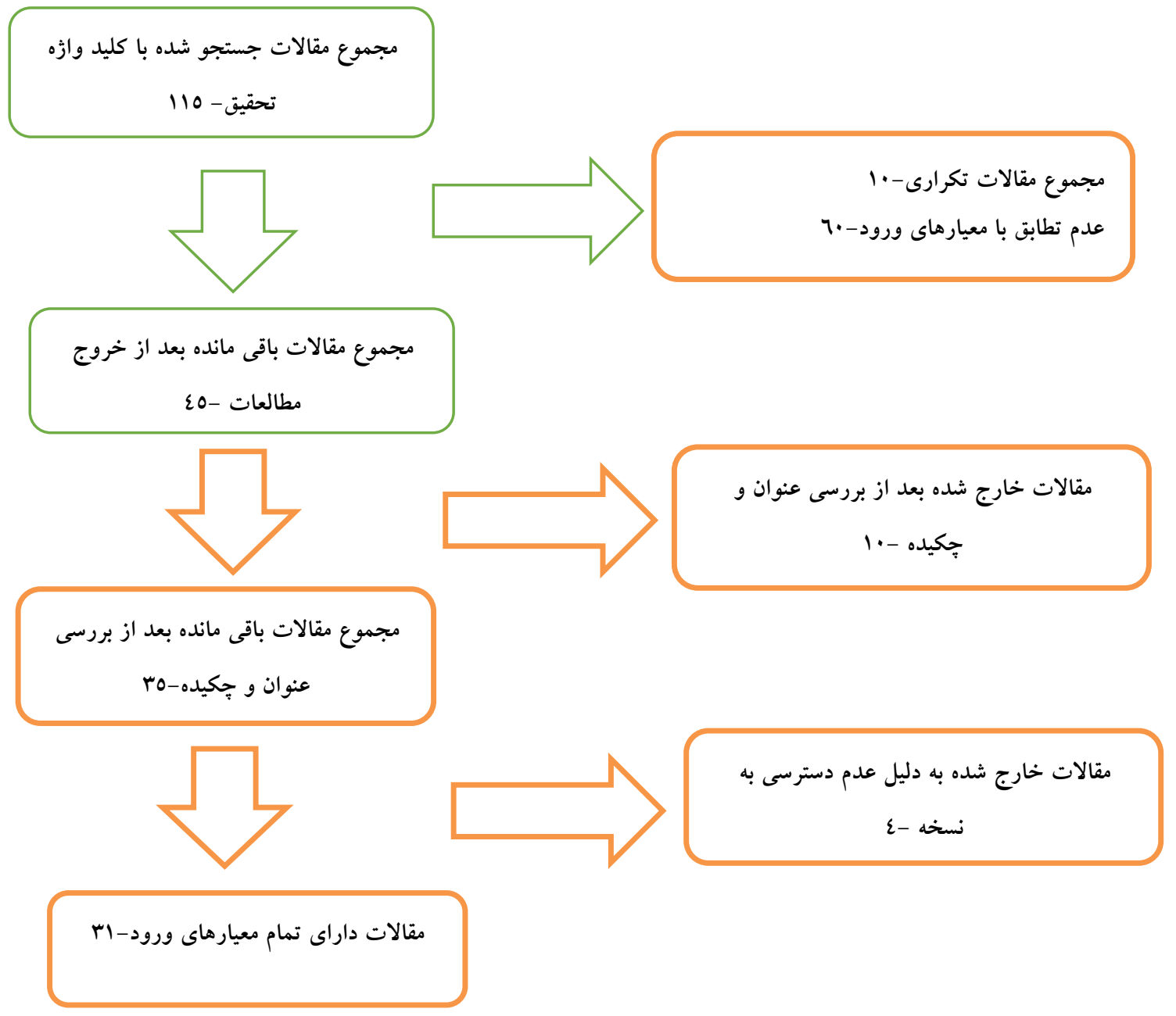

شكل شماره (: شيوه انتخاب مطالعات

يرستارى انجام شده بود. مقالات مورد بررسى حول ينج

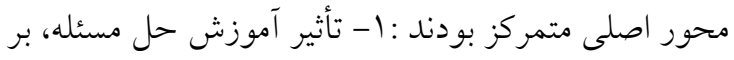
توانايىهاى دانشجويان : برستارى كشور، ب- ديدكاه

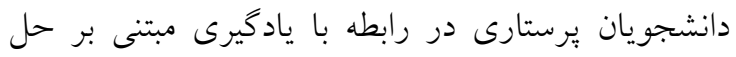

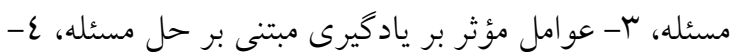

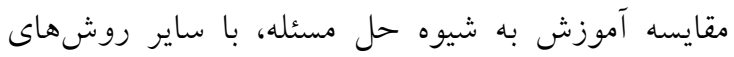

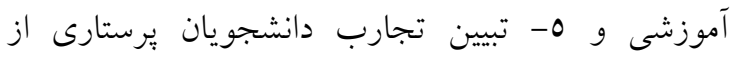

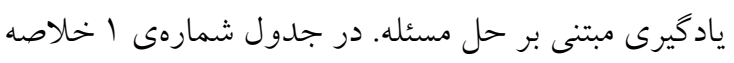

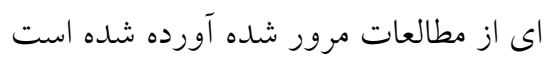

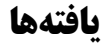
در مجموع 110 مورد مقاله با اين كليدوازمها يافت شد كه بعد از بررسى دقيق، الب مقاله مطابق با هدف يزوهش بود. بيشتر مطالعات انجام شده در اين حوزه به روش نيمه تجربى (·r مطالعه)، هفت مطالعه به روش توصيفى، دو مطالعه به روش كيفى، تنها يك مورد به روش مرورى و

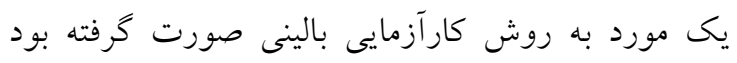

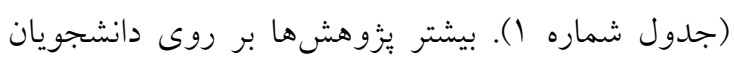

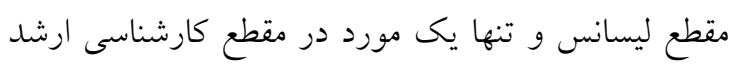


جدول شماره ا: مطالعات انجام شده در رابطه با يادَيرى مبتنى بر حل مسأله در رشته يرستارى در ايران

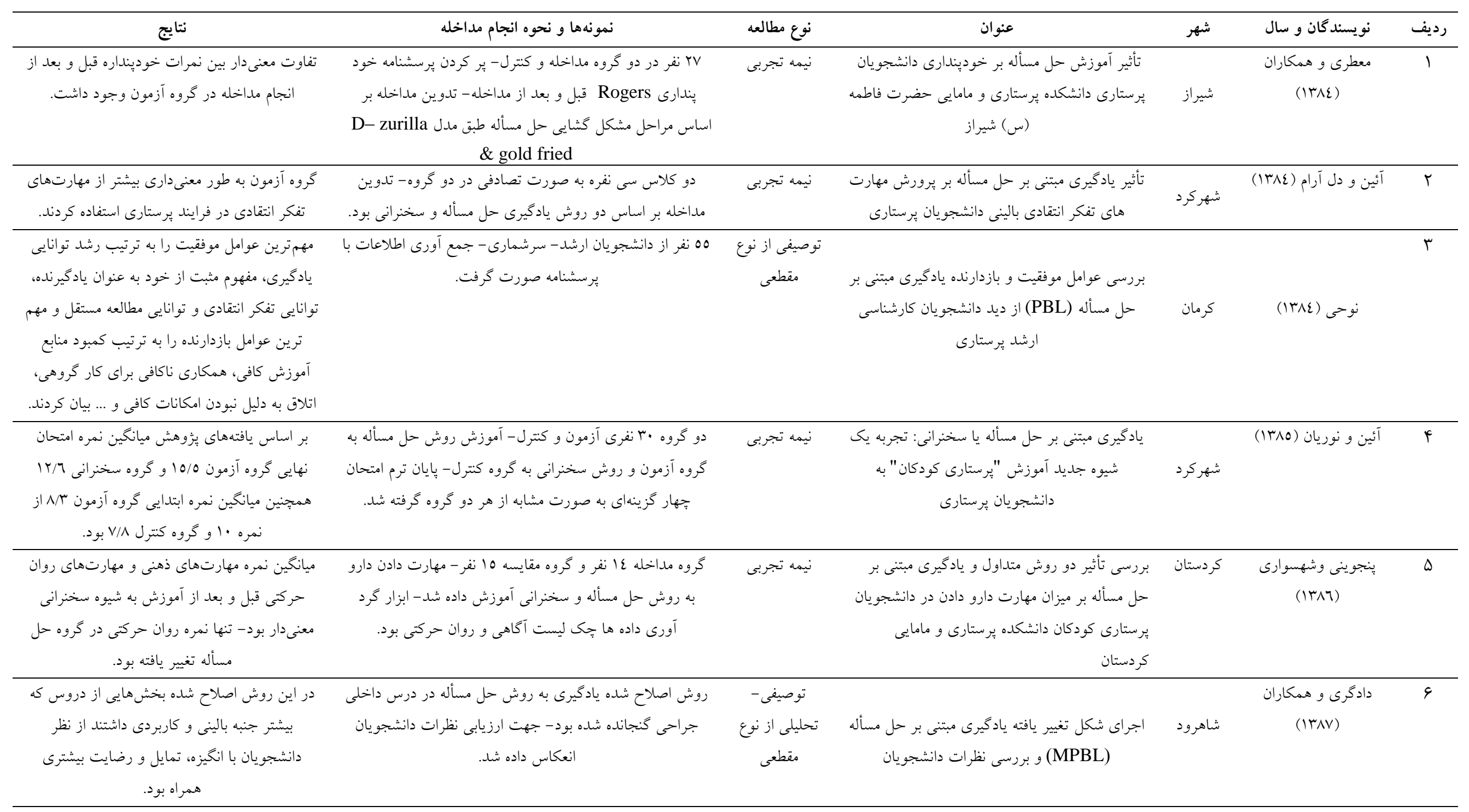




\begin{tabular}{|c|c|c|c|c|c|c|}
\hline 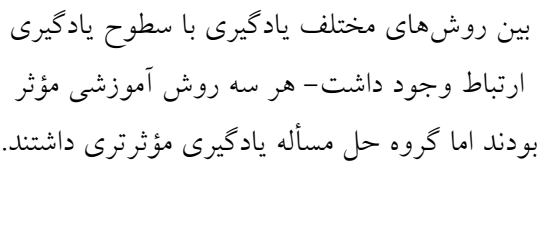 & 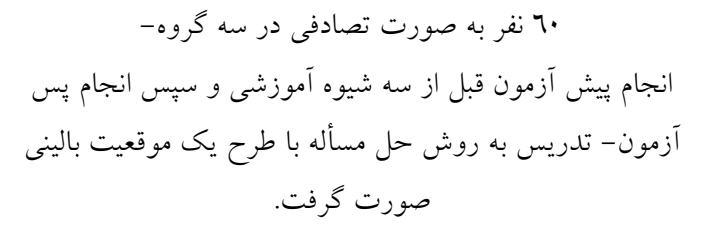 & نيمه تجربى & 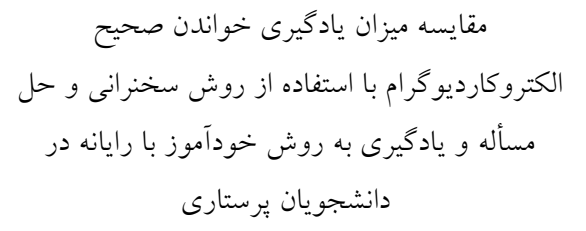 & تهران & 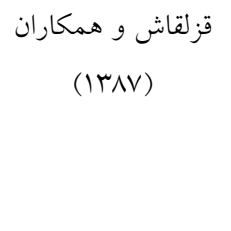 & V \\
\hline 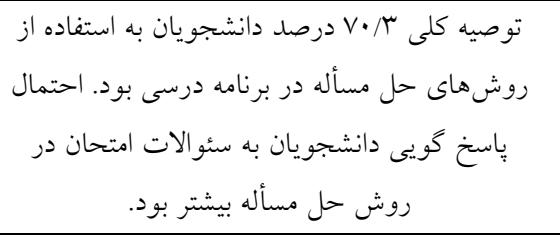 & 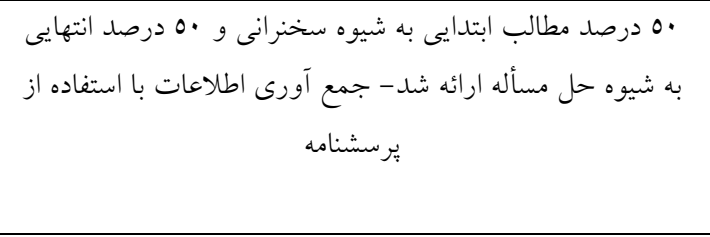 & تحليلى از نوعى - مقطعى & 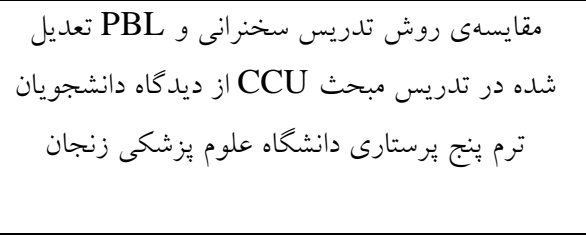 & زنجان & 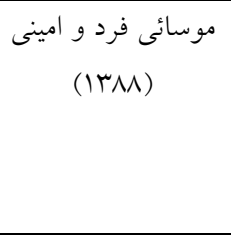 & $\wedge$ \\
\hline 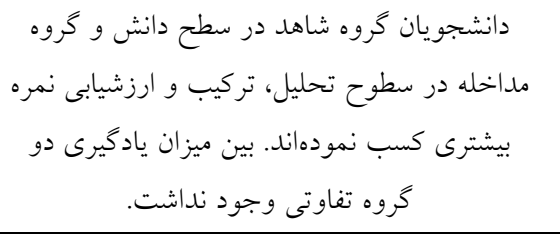 & 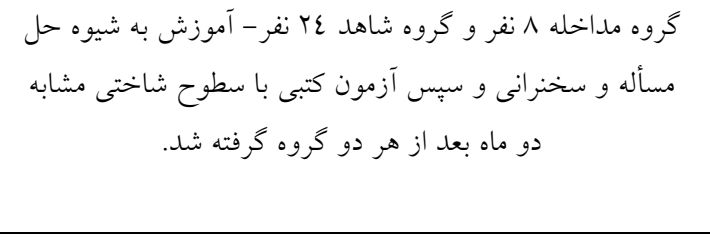 & نيمه تجربى & 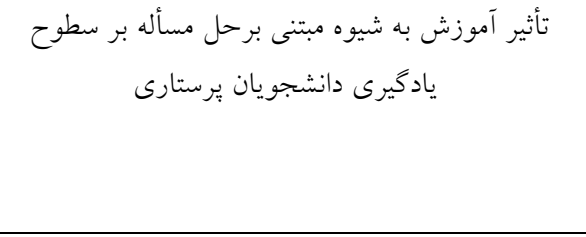 & كلستان & 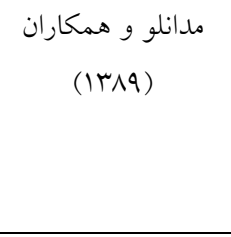 & 9 \\
\hline 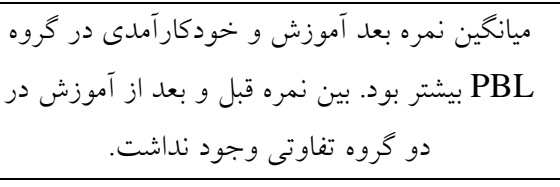 & 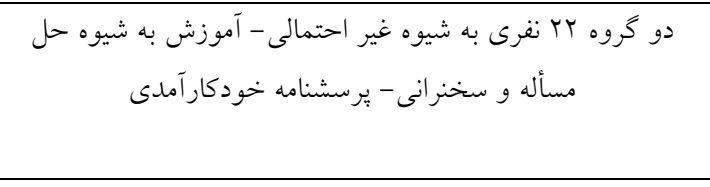 & نيمه تجربى & 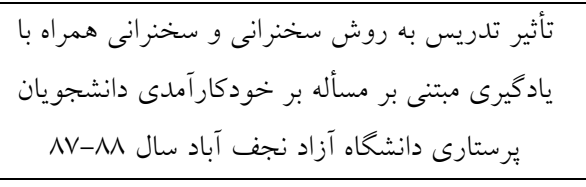 & نجف آباد & 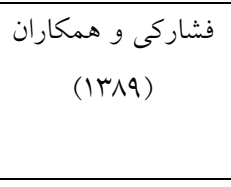 & 1 . \\
\hline 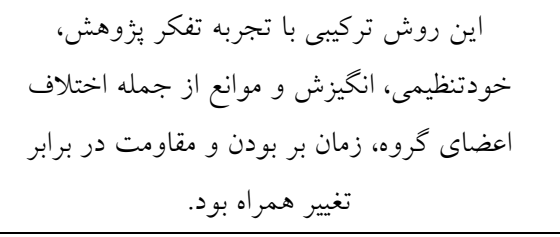 & 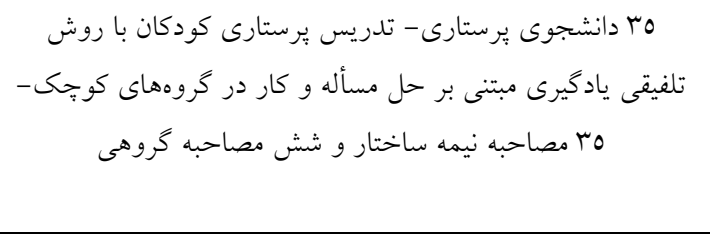 & كيفى & 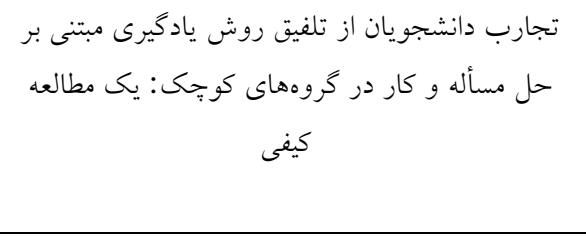 & سبزوار & 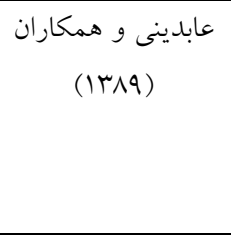 & 11 \\
\hline 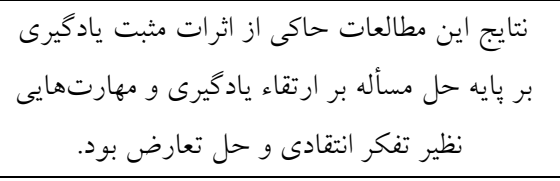 & 11 مطالعه با رعايت گامهاى يادگيرى مبتنى بر حل مسأله انتخاب & مرورى & استفاده از روش يادگيرى بر پِايه مسأله در آموزش & اصفهان & 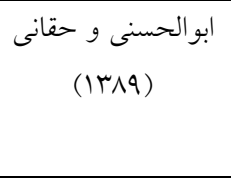 & IT \\
\hline 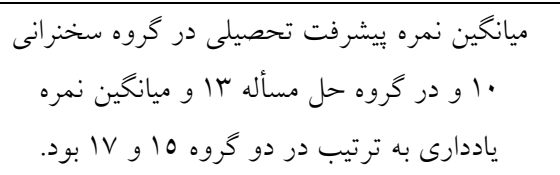 & 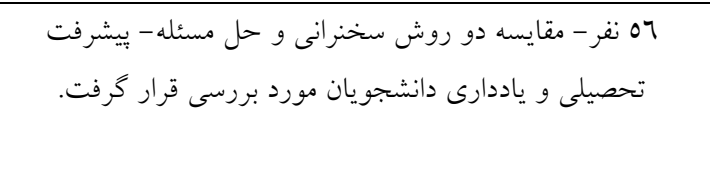 & نيمه تجربى & سخترانى يا آموزش مبتنى بر حل مسئله: مقايسه دو & تبريز & 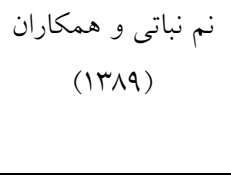 & س \\
\hline
\end{tabular}




\begin{tabular}{|c|c|c|c|c|c|c|}
\hline 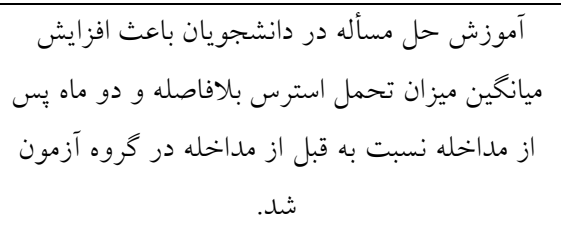 & 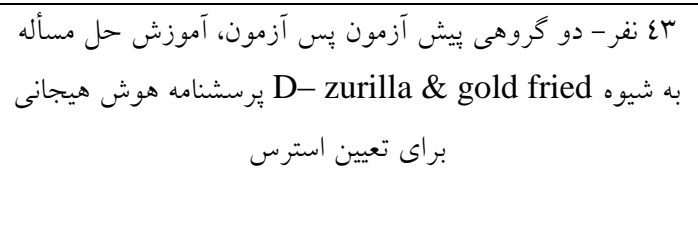 & نيمه تجربى & 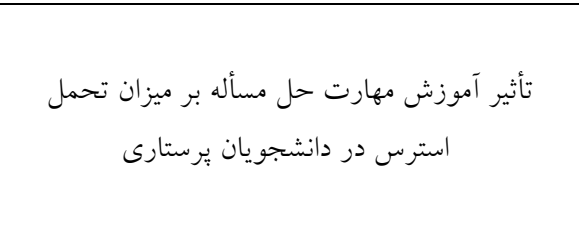 & شيراز & 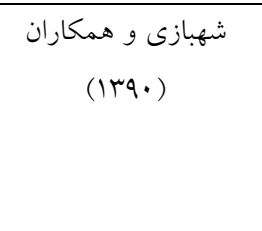 & If \\
\hline 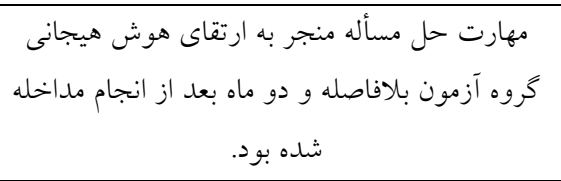 & 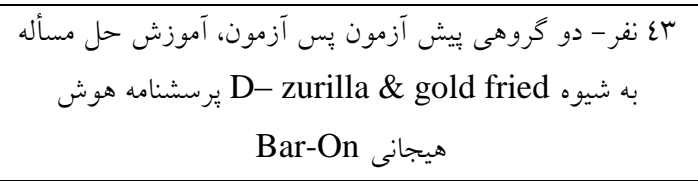 & نيمه تجربى & 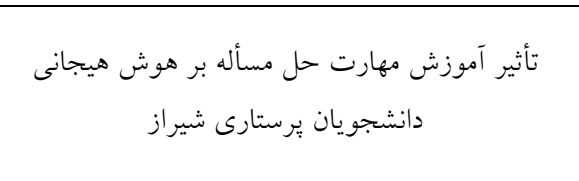 & شيراز & 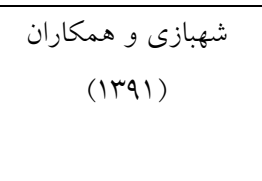 & 10 \\
\hline 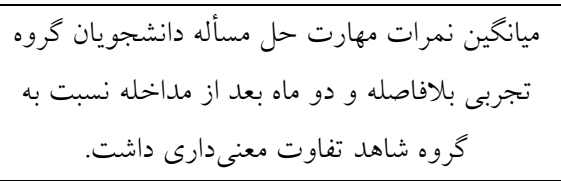 & 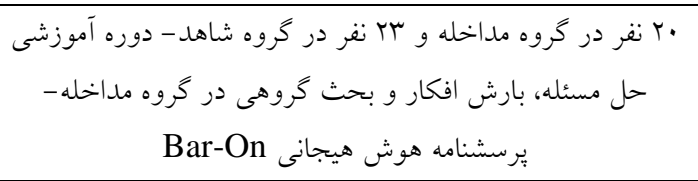 & تصادفى كنترل & 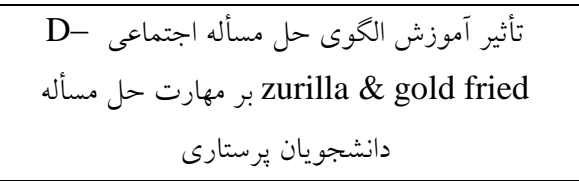 & شيراز & 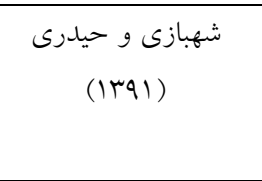 & 19 \\
\hline 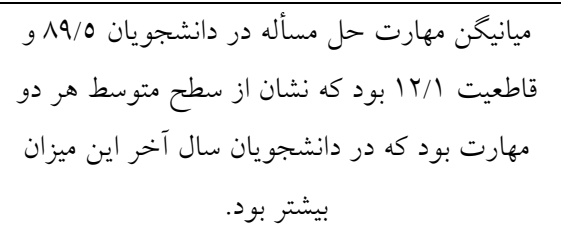 & 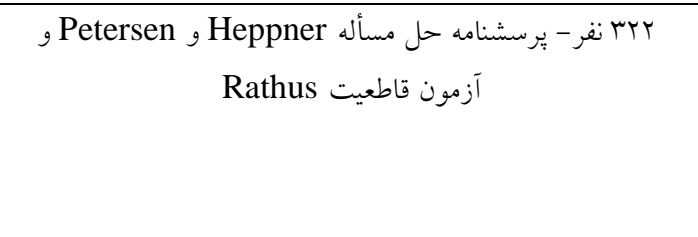 & توصيفى از نوع & بررسى همبستخى درى از توانايى حل مسأله با & تهران & 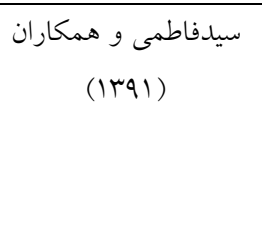 & IV \\
\hline 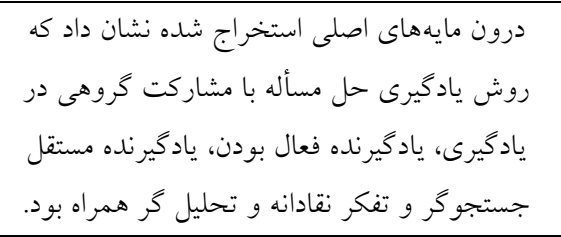 & 10 نفر به شيوه مصاحبه نيمه ساختار، حضورى و گروه متمركز & كيفى & تجارب يادكيرى مشاركتى در آموزش مسأله محور: & كرمان & 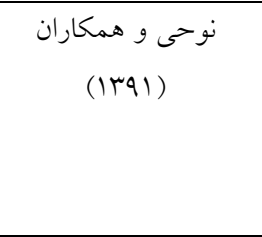 & 11 \\
\hline 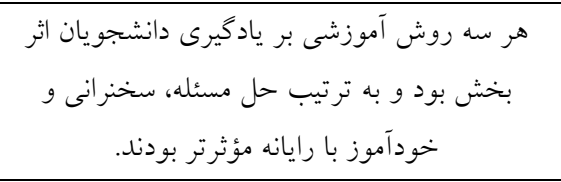 & 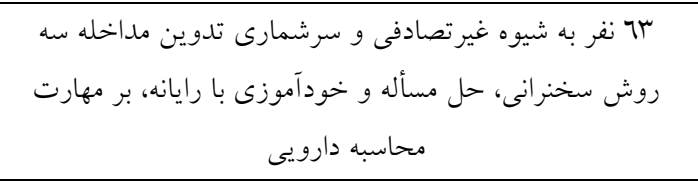 & نيمه تجربى & با مقايسه سه روش سخنرانى، حل مسأله و خودآموزى بر مهارت محاسبه دارويى درس مراقبتهاى & تهران & 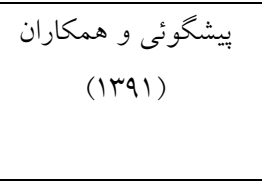 & 19 \\
\hline ميانكين نمرات ديدگًاه دانشجويان از موفقيت دره مداخله افزايش بيدا كرده بود. & 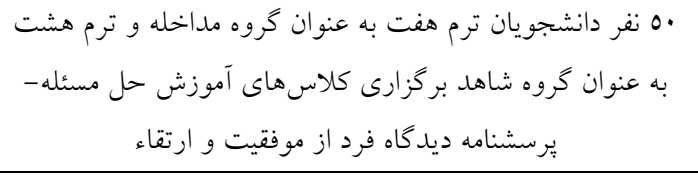 & نيمه تجربى & 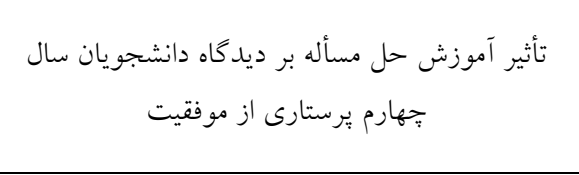 & اروميه & 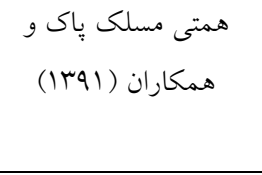 & $r$. \\
\hline
\end{tabular}




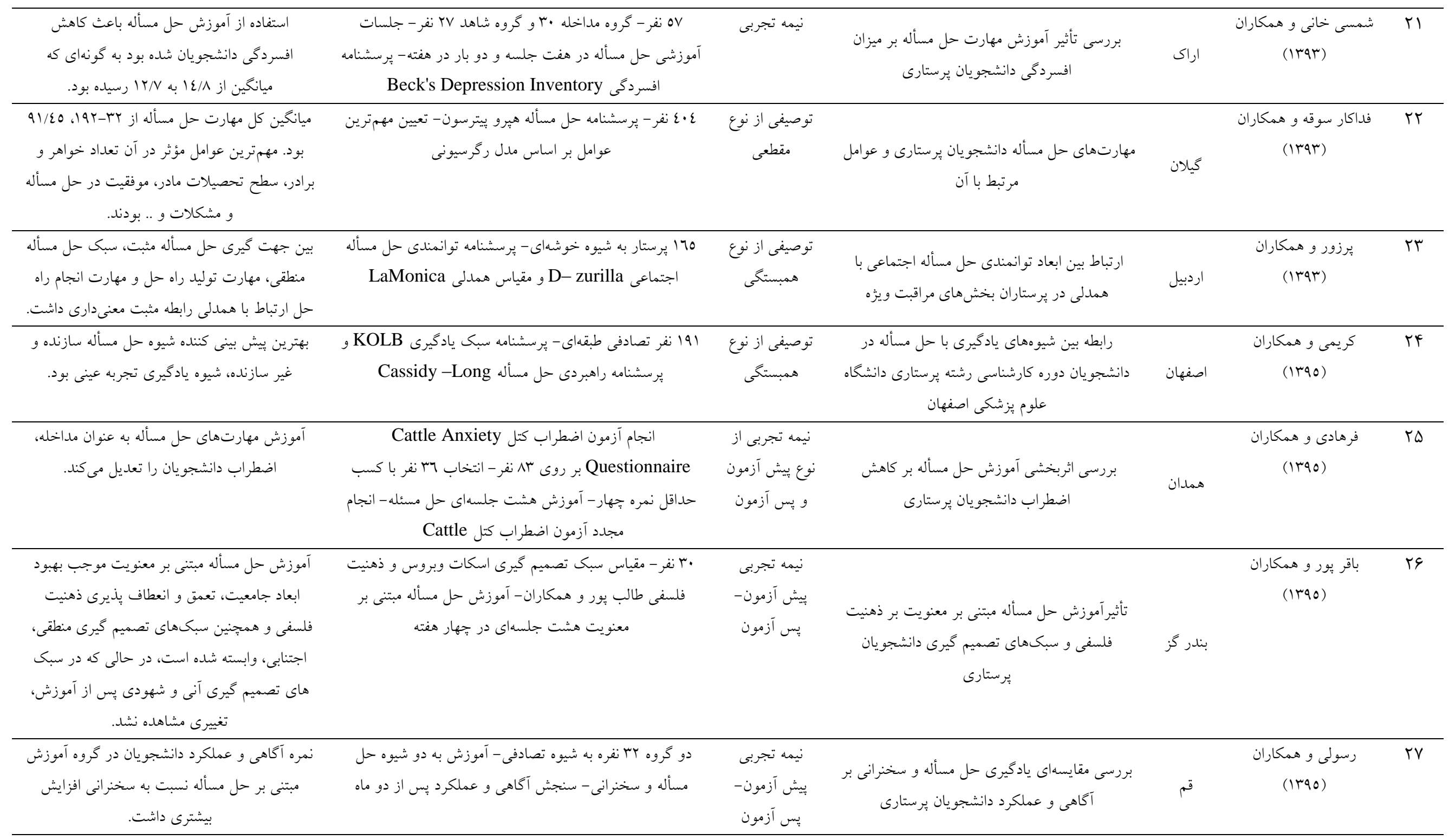




\begin{tabular}{|c|c|c|c|c|c|c|}
\hline 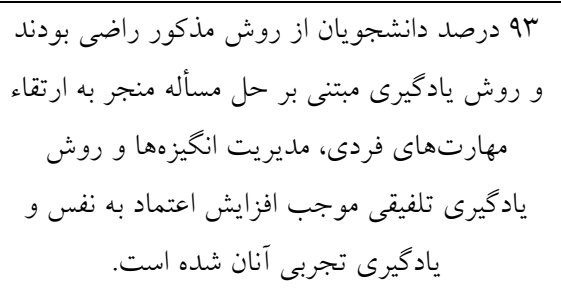 & 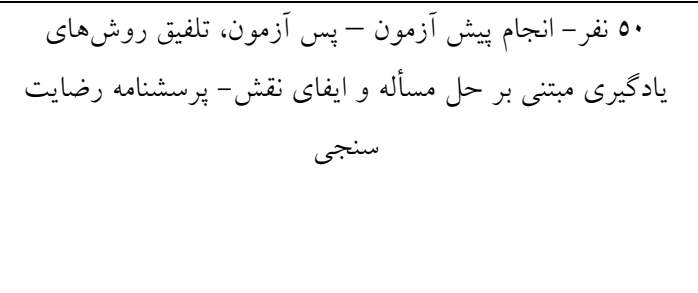 & نيمه تجربى & 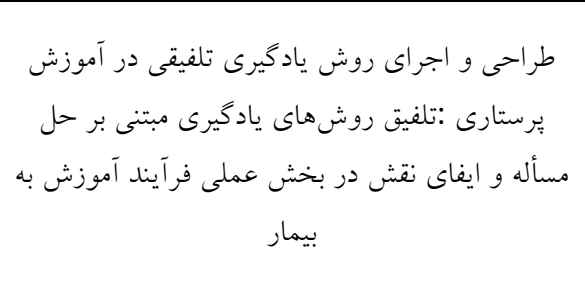 & جهرم & شهسوار اصفهانى & $r \Lambda$ \\
\hline 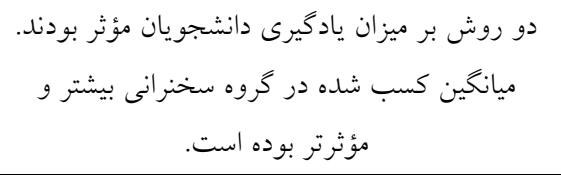 & كروه آزمون 10 نفر و شاهد ع آنقر - آموزش حل مسأله به گروه & 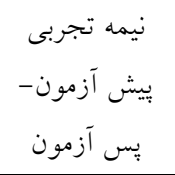 & 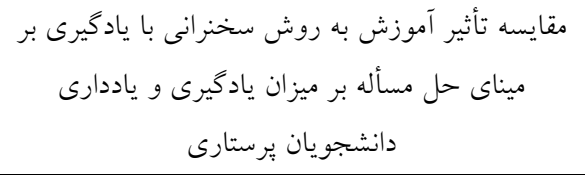 & رشت & 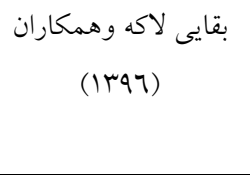 & $r q$ \\
\hline 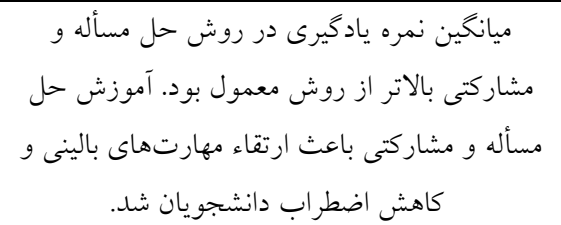 & 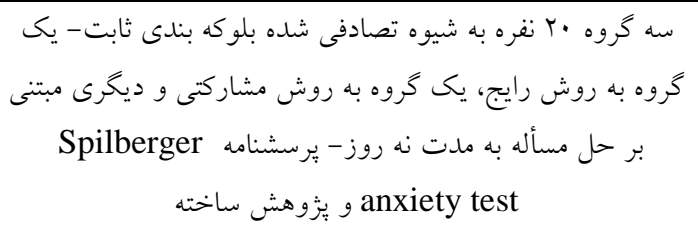 & نيمه تجربى & 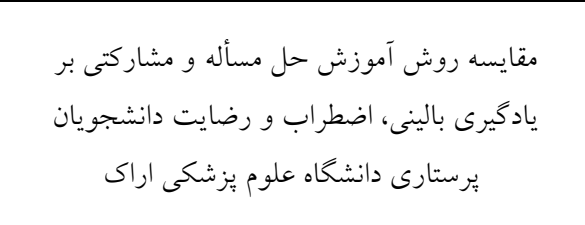 & اراى & 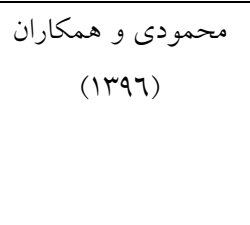 & $r$. \\
\hline 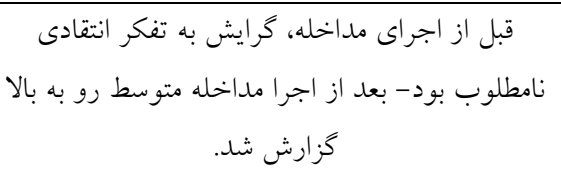 & 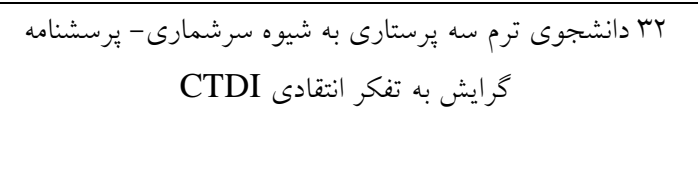 & 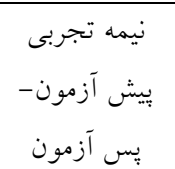 & 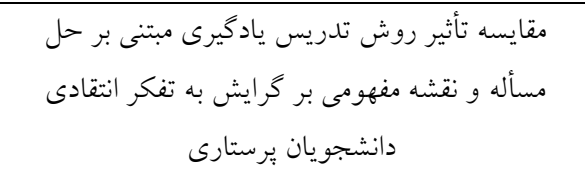 & خمين & $\begin{array}{l}\text { صالحى و همكاران } \\
\text { (1)97 (1) }\end{array}$ & ו ו \\
\hline
\end{tabular}


خودكارآمدى دانشجويان يرستارى دانشگاه آزاد اسلامى

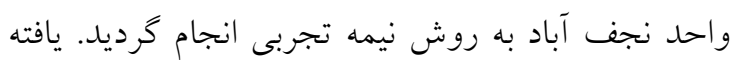

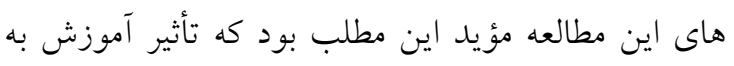

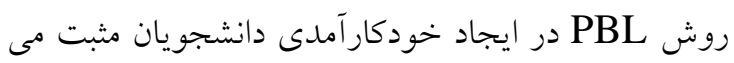

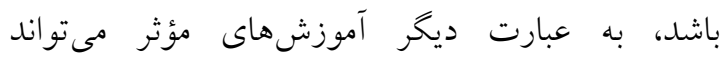

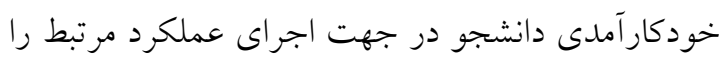
ارتقاء دهد. اين مطالعه توصيه مىكند دست اندركاران

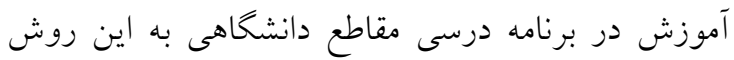

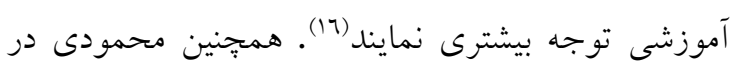

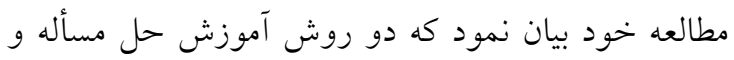
مشاركتى باعث ارتقاء مهارتهاى بالينى و كاهش اضطراب

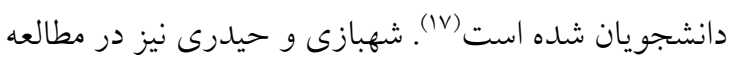

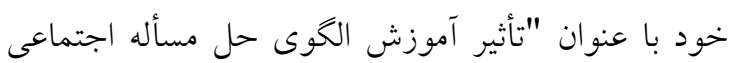
D- zurilla \& gold fried دانشجويان برستارى" كه به روش كارآزمايى بالينى كنترل

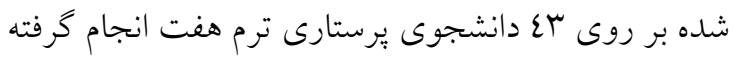
بود، دريافتند ميانخين نمر ات مهارت حل مسأله دانشجويان كروه تجربى در مر احل بلافاصله و دو ماه يُ إن از مداخله،

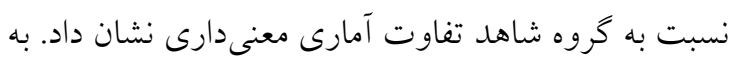
طورى كه دانشجويان با فراخرفتن مهارت حل مسأله

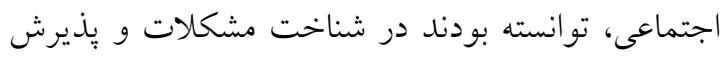

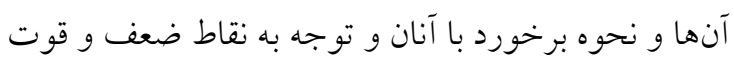

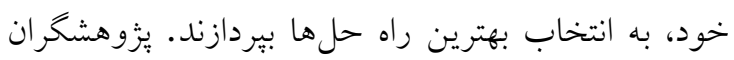

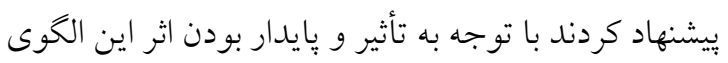

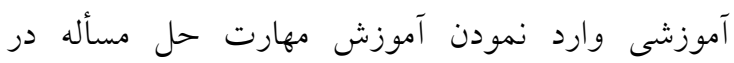

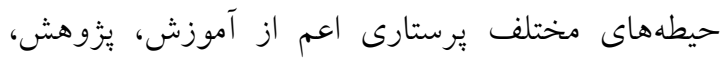

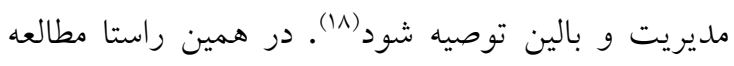

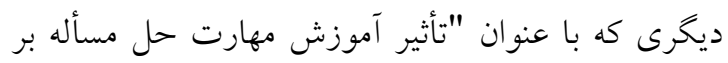

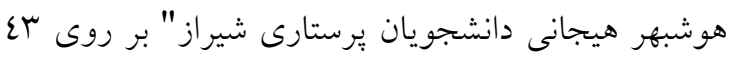

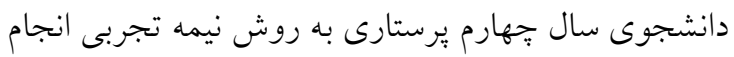

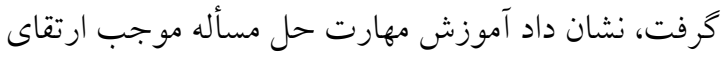
هوش هيجانى دانشجويان گروه تجربى نسبت به كروه

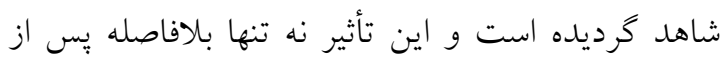

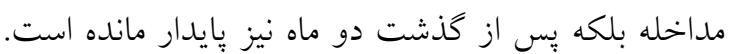

\section{بحث و نتيجه تيرى}

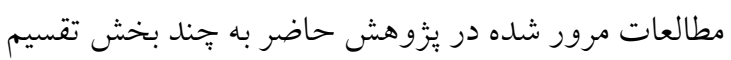
بندى شدند كه عبارت بودند از: ا- مطالعات مرتبط با تأثير

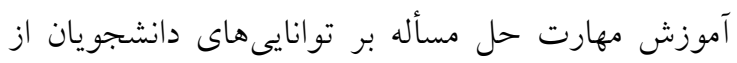

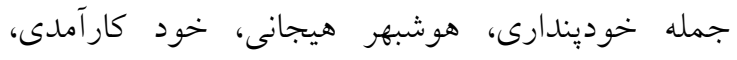

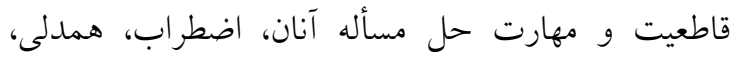
ديدگاه موفقيت، سبكهاى تصميم گيرى و يادگيرى،

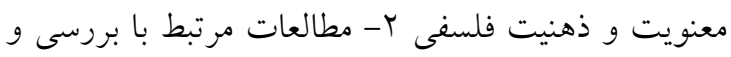

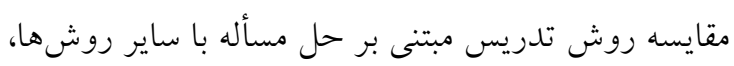

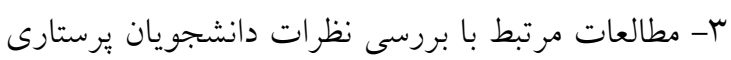

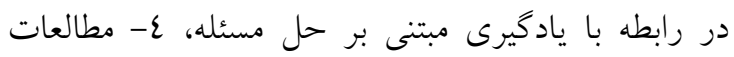
كيفى، 0- يادگيرى حل مسأله و عوامل مؤثر بر آن.

تأثير آموزش حل مسأله بر توانايىهاى دانشجويان

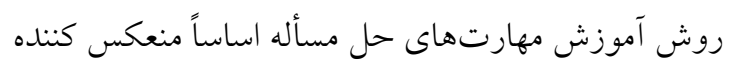

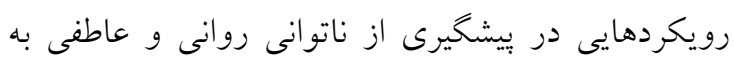

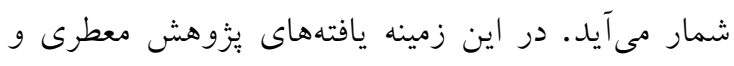

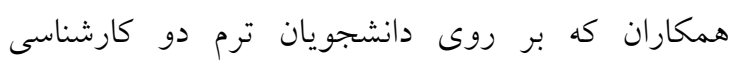

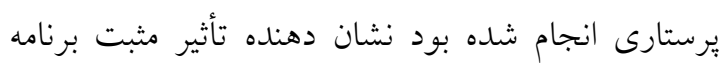

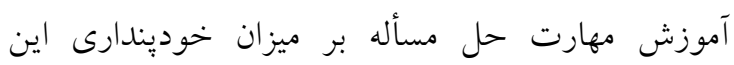
دانشجويان بود. جرا كه دانشجويان با بهره جستن از

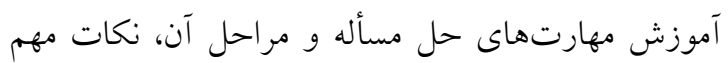

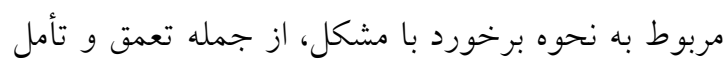

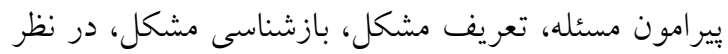
كرفتن راه حل هاى مختلف و متعدد و انتخاب بهترين راه

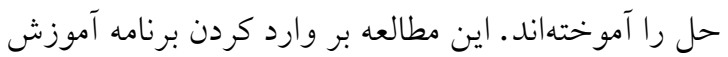
حل مسأله در برنامه هاى آموزش عالى تأكيد داشت. با توجه به اين كه در حرفه يرستارى فقط توانايى انجام وظايف كافى نيست بلكه توانايى تركيب دانش، نخرش، ارزشها ئرسا

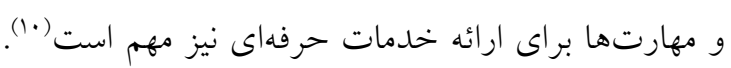
همجنين اجراى برنامه آموزش يادكيرى مبتنى بر حل مسأله

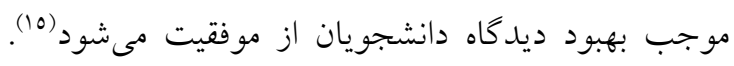

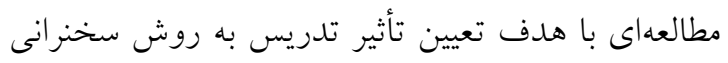

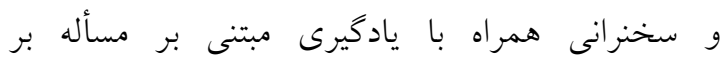


آموزش حل مسأله بر كاهش اضطراب دانشجويان يرستارى

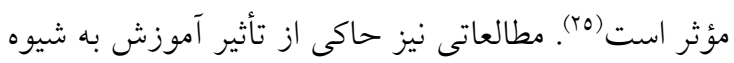
حل مسأله بر سطوح شناختى يادگيرى مىباشد. مطالعه

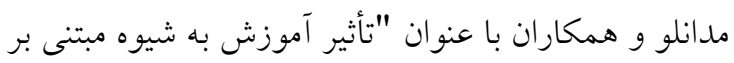

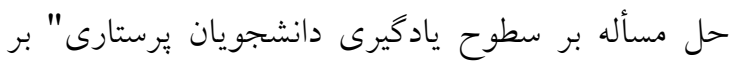
روى دانشجويان ترم ينج يرستارى، حاكى از تفاوت آمارى ياري معنى دارى در سطوح شناختى يادگيرى بود به طورى كه دانشجويان گروه سخنرانى در سطح دانش و كروه حل مسأله در سطوح تحليل، تركيب و ارزشيابى نمره بيشترى

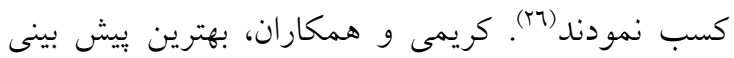
كننده حل مسأله سازنده و غير سازنده را، شيوه يادگيرى

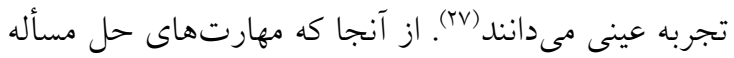
در بالاترين سطح شناختى انسان قرار دارد و از لهان ارزشمندترين اهداف تربيت آموزشى به حساب مى آيند ييشنهاد مى گردد اساتيد يرستارى در برخى دروس اين

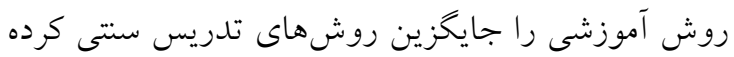
تا موجبات ارتقاى توانايىهاى روانى و عاطفى دانشجويان يرستاران بيش از يِيش فراهم كردد.

مقايسه آموزش به شيوه حل مسأله با ساير روشهاى آموزشى در يزوهش آئين و نوريان يادگيرى در دانشجويانى كه با

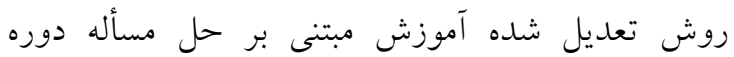

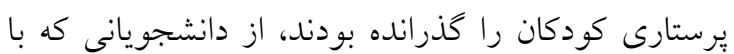

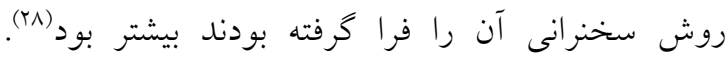

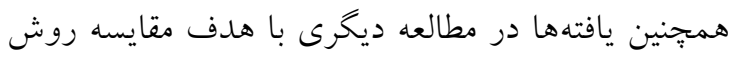
تدريس سخنرانى و PBL تعديل شده در تدريس مبحث CCU دانشجويان يرستارى جذابيت و و رضايتمندى، ميزان ماندكارى ذهنى مطالب (عمق يادگيرى)، كاربردى بودن

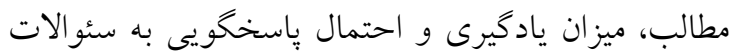

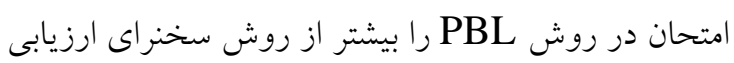
كردند و نهايتًا توصيه كلى VV V V درصد دانشجويان اين بوده است كه استفاده از روش تدريس PBL درديه كرد كلاس
دانشجويان با فراكرفتن مهارت حل مسأله اجتماعى، توانستهاند در شناخت مشكلات و يذّيرش آنها و نحوه

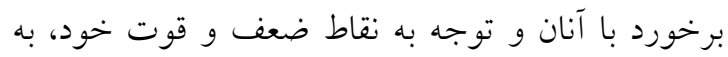

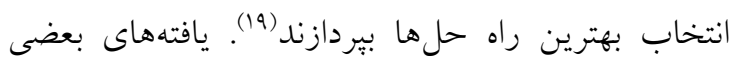

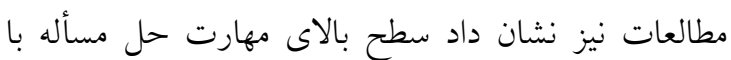

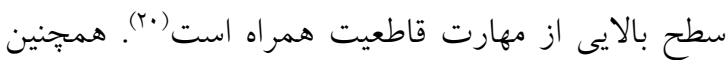

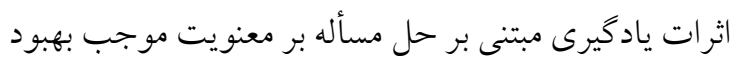

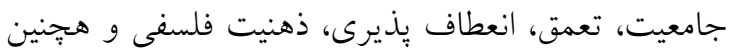
سبكهاى تصميم گيرى منطقى، اجتنابى و وابسته مى لمى

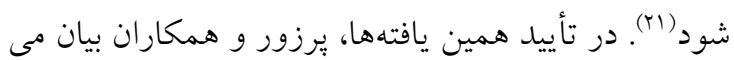

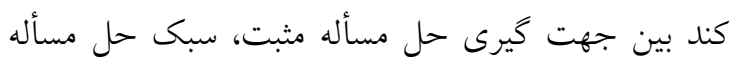
منطقى، مهارت توليد راه حل و مهارت انجام راه حل با سل

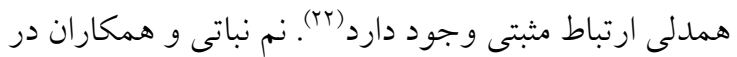
مطالعه خود نشان دادند كه يادگيرى مبتنى بر حل مسأله مى تواند همراه با آن در بيشرفت تحصيلى و ياددارى دانشجويان مؤثر واقع شود. علاوه بر اين شيوه يادگيرى مبتنى بر حل مسأله در درس كودكان قابليت اجرا دارد و اهداف را تحقق مىبخشد (rr). با توجه به اين كه امروزه مهارتهاى حل مسأله و تصنديم

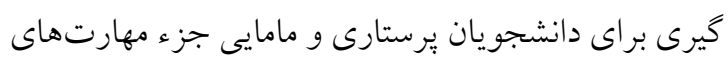

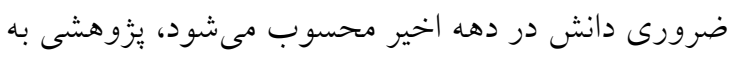

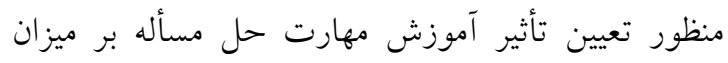

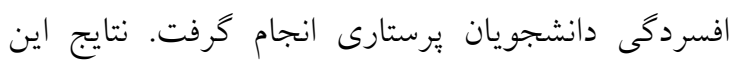
مطالعه نيمه تجربى مؤيد اين مطلب بود كه مهارت حل دان

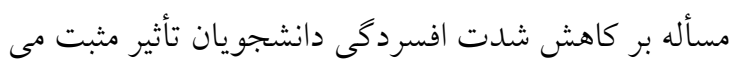

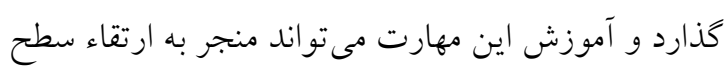

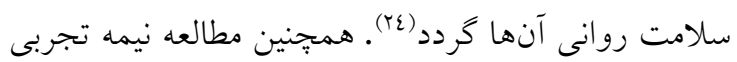

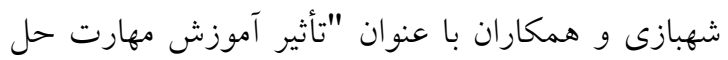

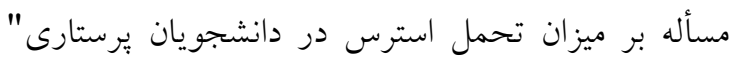
نشان داد آموزش حل مسأله باعث افزايش ميانخين ميزان

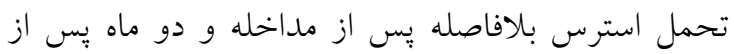
مداخله نسبت به قبل از مداخله در گروه آزمون شد (19). فرهادى و همكاران در مطالعه نيمه تجربى نتايج خود را مدار

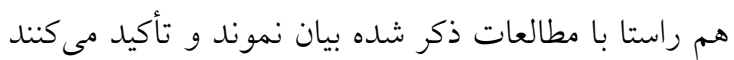


ولى تأثير روش خودآموز با رايانه كمتر بوده است.

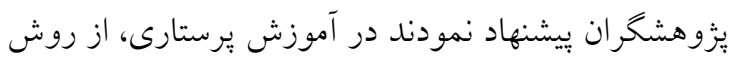

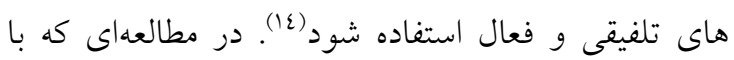
هدف مقايسه روش تدريس يادگيرى مبتنى بر حل مسأله

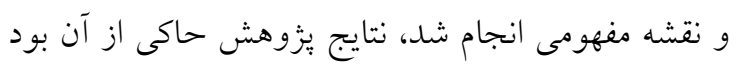

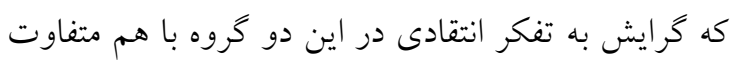

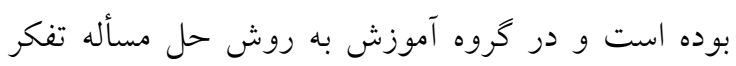
انتقادى دانشجويان بيشتر است. همجنين اين تفاوت در زير

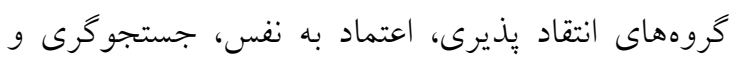
رشد يافتكى نيز وجود داشت كه در گروه حل مسأله بيشتر بود. اما بين حقيقت جويى، قدرت تجزيه و تحليل و قدرت

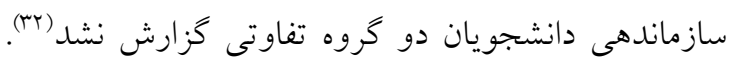

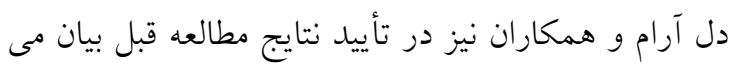
كنند كه دانشجويانى كه از روش تدريس مبتنى بر حل

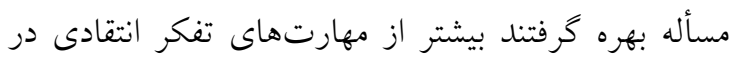

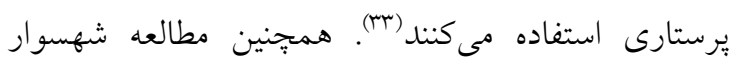

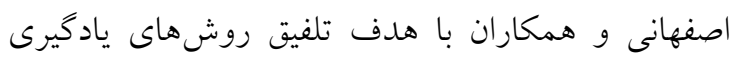
مبتنى بر حل مسأله و ايفاى نقش در بخش عملى فرانى فرايند

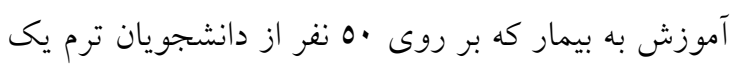

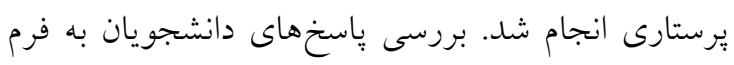

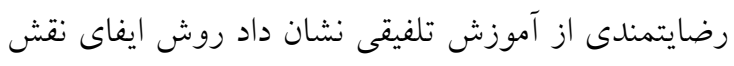

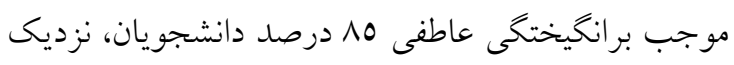
تر احساس كردن خود به صحنه نمايش و به كار گيرى همه

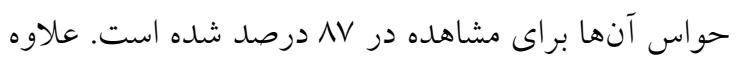
بر اين روش يادگيرى مبتنى بر حل مسأله منجر به ارتقاء

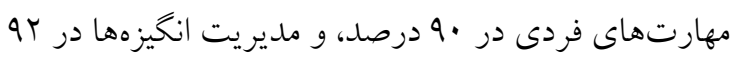
درصد و روش يادكيرى تلفيقى نيز موجب افزايش اعتماد

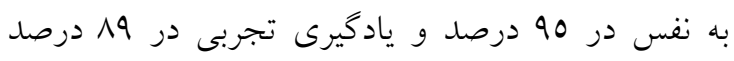

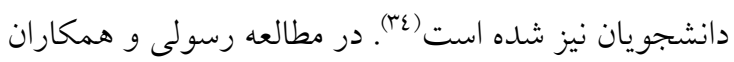

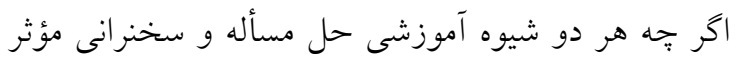

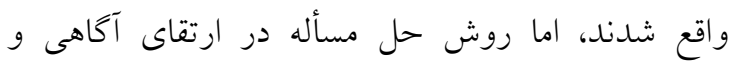

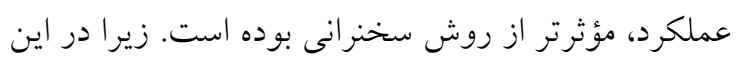

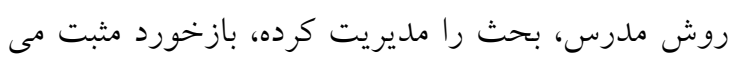

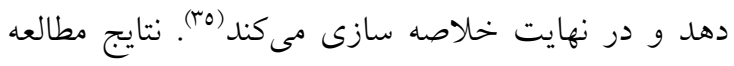

هاى درسى بهتر است (T9). در حالى كه مطالعه ينجوينى و

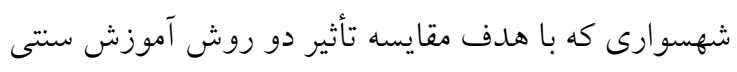
و مبتنى بر حل مسأله بر مهارتهاى دارو دادن دانشجويان

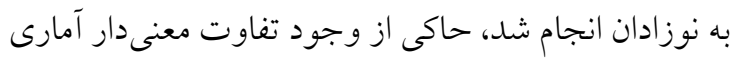

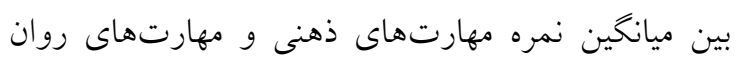

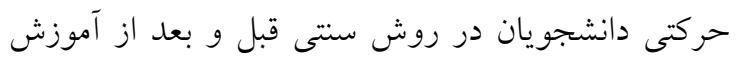
بود ولى در گروه PBL اين اختلاف در مورد ارتقاء مهارت

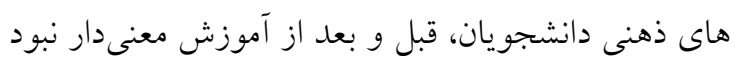

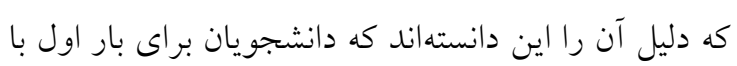

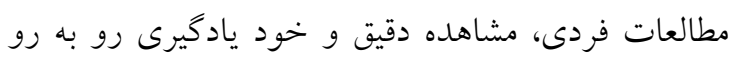

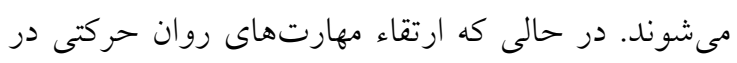

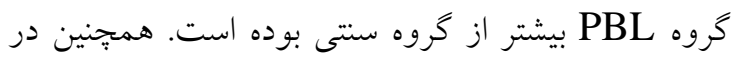
اين مطالعه مشخص شد كه ميزان رضايتمندى دانشجويان

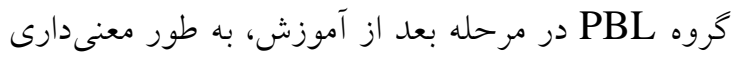

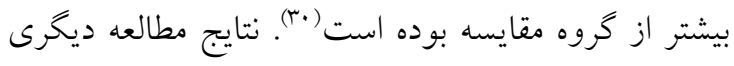

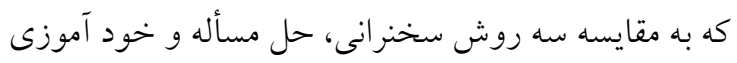

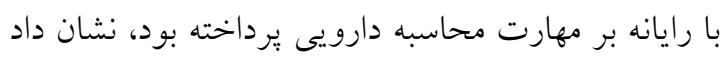

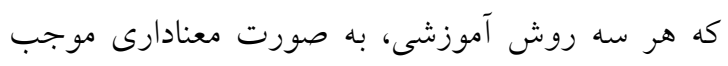

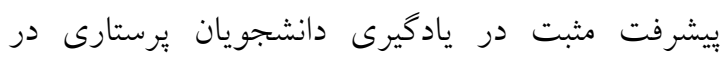

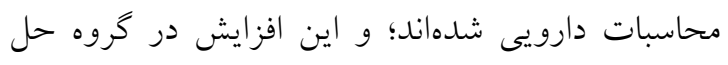

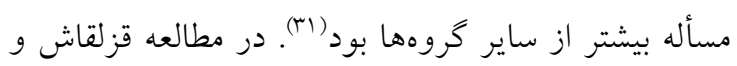

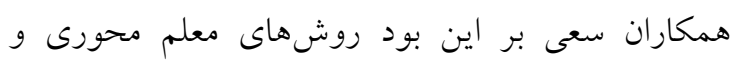
يادگيرنده محورى مورد بررسى و مقايسه قرار كيرند.

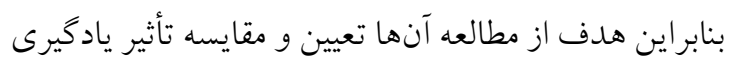

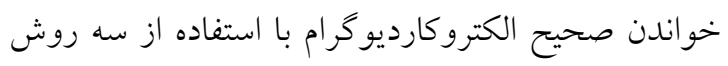
سخنرانى (معلم محورى) و حل مسأله و خودآموز با رايانه

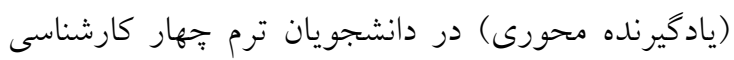

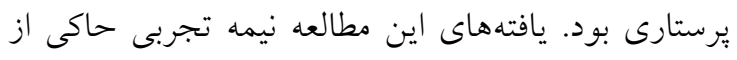

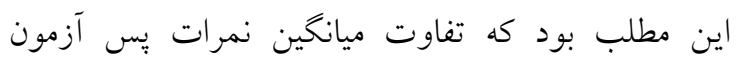

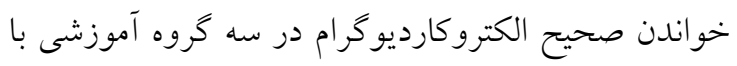

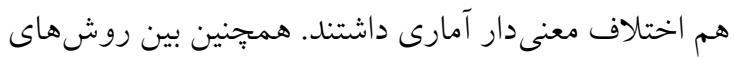
مختلف يادگيرى با سطوح يادگيرى دانشجويان ارتباط

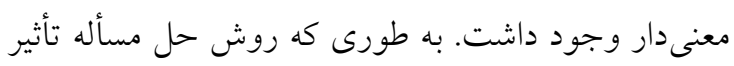

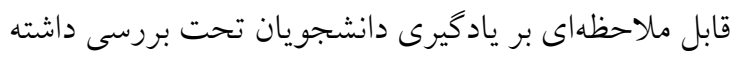


هدايت كافى در دستيابى و استفاده از منابع از عوامل عمده

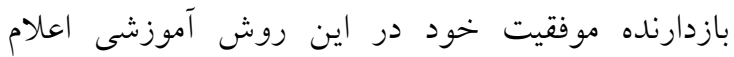

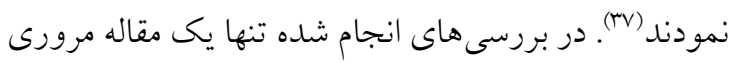

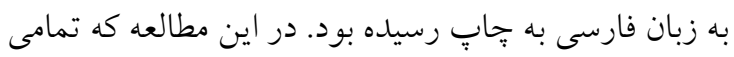

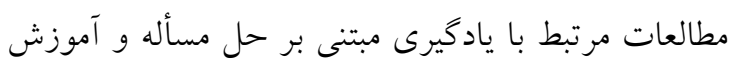

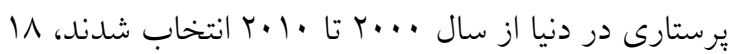
مطالعه مرتبط مورد تجزيه و تحليل قرار گرفتند. اين مطالعه دئه

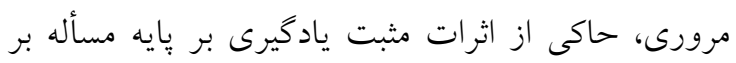

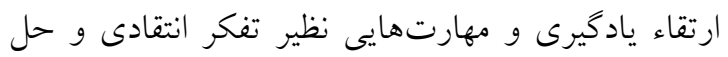

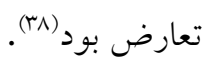

تجارب دانشجويان از يادگيرى مبتنى بر حل مسأله (مطالعات كيفى) در ميان مقالات به جإِ رسيده به زبان فارسى، دو يزوهش با روش كيفى انجام گرفته بود. در مطالعه نوحى و همكاران با عنوان "تجارب يادكيرى مشاركتى در آموزش مسأله

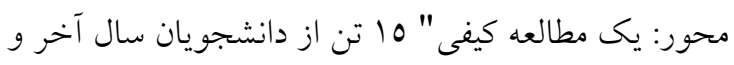

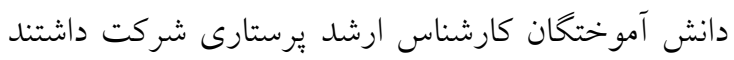

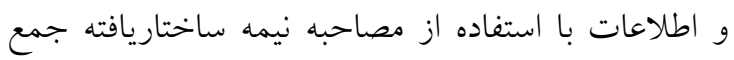
آورى شد. درون مايههاى اصلى استخراج شده از تحليل

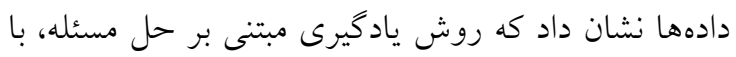

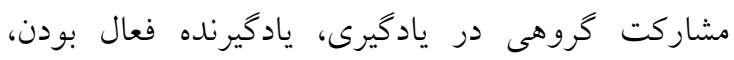
يادگيرنده مستقل جستجو گر و تفكر نقادانه و تحليل گرايانه

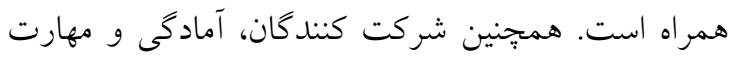

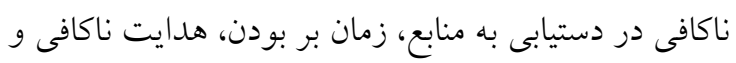

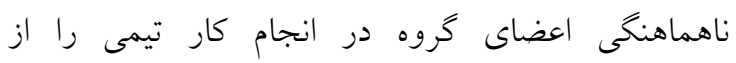
محدوديتهاى اين رويكرد دانستند(ra). در ديخر مطالعه

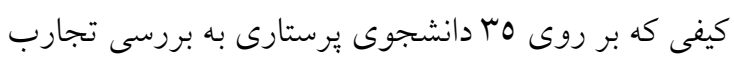

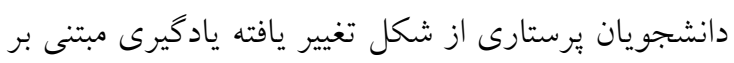

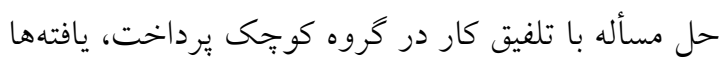
نشان داد كه تلفيق روش يادگيرى مبتنى بر حل مسأله و

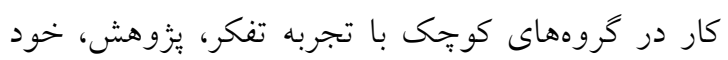

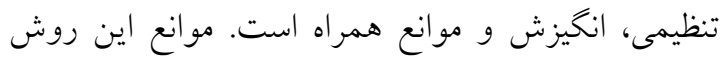

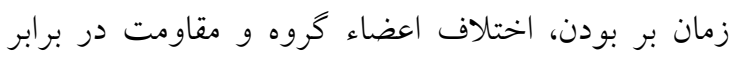

بقايى لاكه حاكى از آن بود كه روش سخنرانى بر ميزان

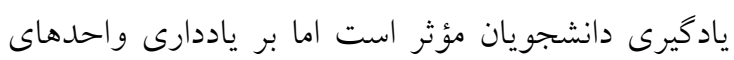

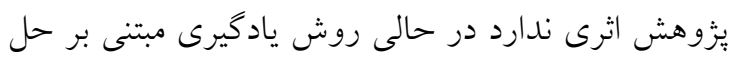

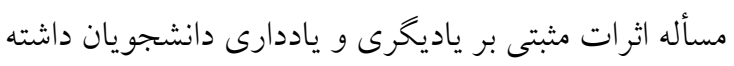

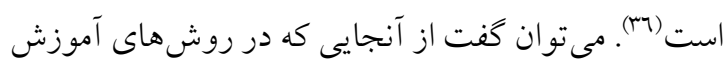
فعال مانند PBL، دانشجويان در فر آيند تدريس مشاركت دارند، همين امر سبب افزايش يادكيرى عميق و اعتماد به

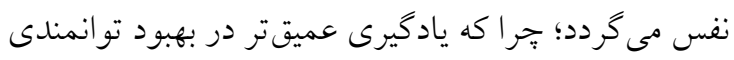
هاى عملى در محيط بالينى بسيار مهم است. در همين راستا

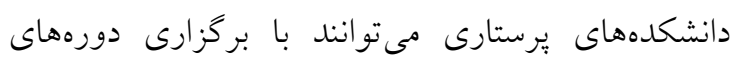

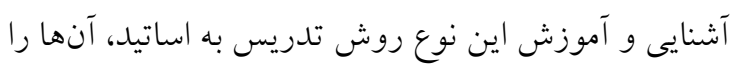

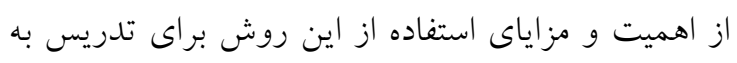

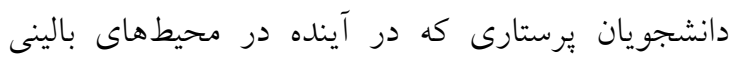
مشغول به كار خواهند بود، آكاه سازند.

ديدگاه دانشجويان در رابطه با يادگيرى مبتنى بر حل مسئله برخى مطالعات به بررسى نظرات دانشجويان يُرستارى در

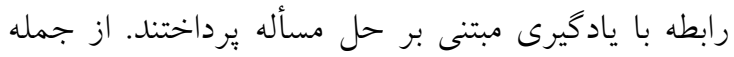

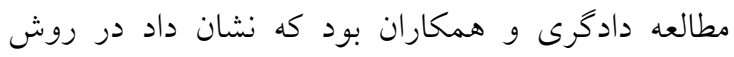

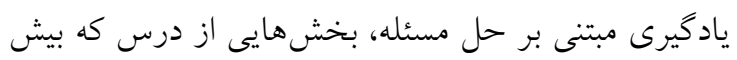

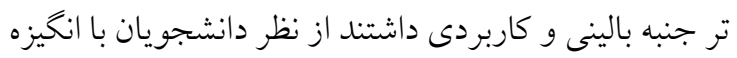
و تمايل درونى بيشترى همر اه بوده است و همحتنين بيشتر دانشجويان از روش اجرا شده رضايت داشتند (1"). همجنين دمنين در مطالعه ديخرى كه به بررسى عوامل موفقيت و بازدارنده يادكيرى مبتنى بر حل مسأله يرداخته بود، اكثريت

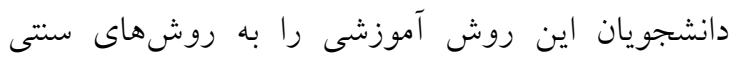

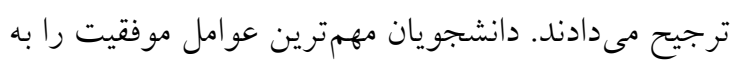

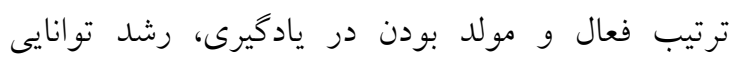

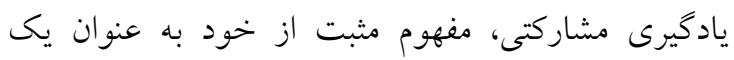

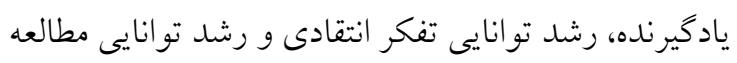

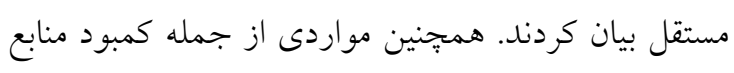
آموزشى كافى، عدم وجود همكارى كافى براى كار كروهى، اتلاف وقت بدليل نبودن امكانات كافى و كمبود 
جانبه آن در آموزش دانشجويان يرستارى مىباشند.

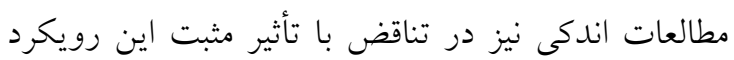

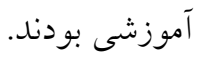
از آنجا كه مرور مطالعات انجام شده اغلب بر ارجحيت و ودن تأثير مثبت روش تدريس يادكيرى مبتنى بر حل مل مسأله نسبت به روشهاى سنتى تدريس دلالت دارد، انتظار مى لي رود اين روش در دانشگاههاى علوم يزشكى كشور

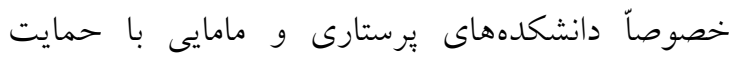

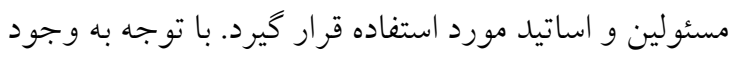
مطالعات متعددى در ارتباط با آموزش مبتنى بر حل مسأله

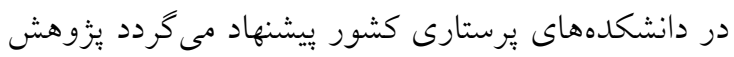

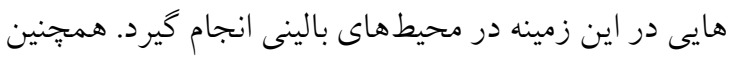

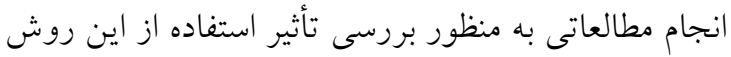

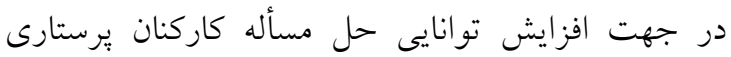
ييشنهاد مى گردد. از محدوديت يزوهش حاضر، عدم وارد كردن مطالعات

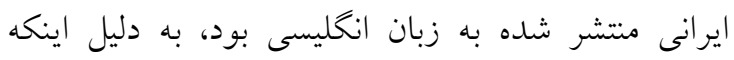

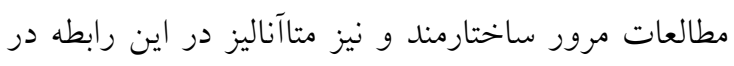

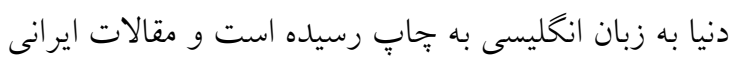

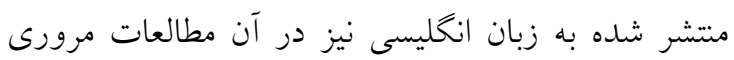

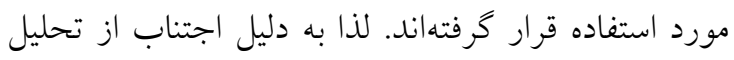
دوباره اين مقالات، مطالعه حاضر متمركز بر مقالات فارسى است. جرا كه تاكنون هيج مقالهى مرورى به تحليل مقالات فارسى در رابطه با اين موضوع نبرداخته است.

تعارض منافع: هيج گونه تعارض منافع توسط نويسندكان بيان نشده است. تقدير و تشكر مطالعه حاضر هيجگگ نه حمايت مالى از سوى هيج مؤسسه

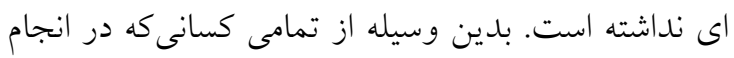
اين يزوهش به ما يارى رساندند، تشكر و قدردانى مى شود.

\section{References}

تغيير بود. همجنين روش تعديل شده حل مسأله در تقويت

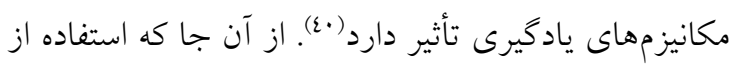
شيوههاى دانشجو محور با ارتقاء تفكر انتقادى و عادات

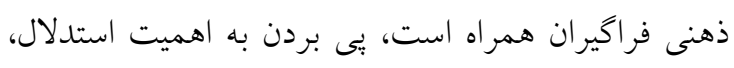

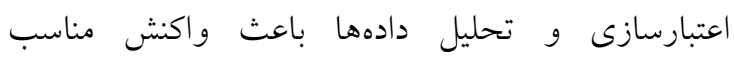
دانشجويان براى بازخورد مى كردد.

عوامل مؤثر بر يادگيرى مبتنى بر حل مسئله

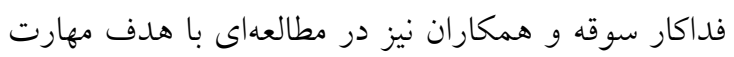

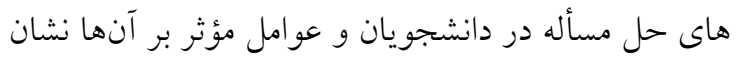

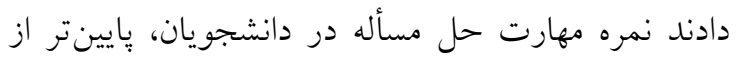

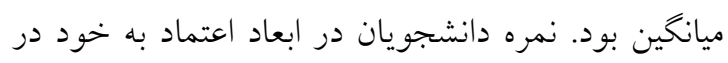

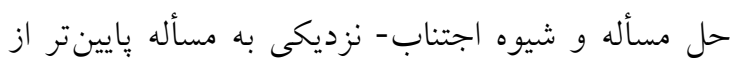

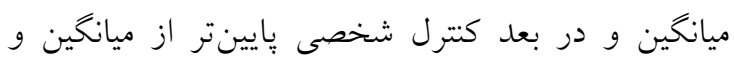

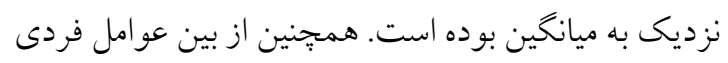

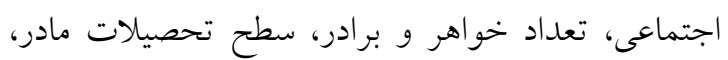

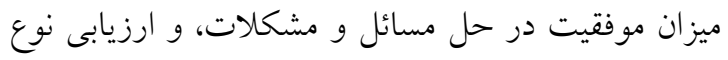

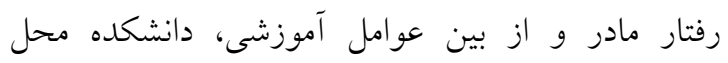

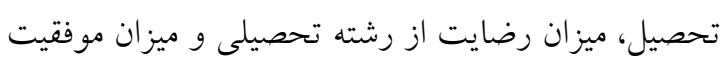

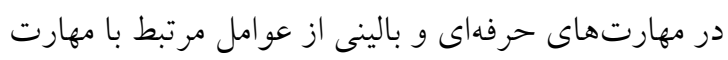

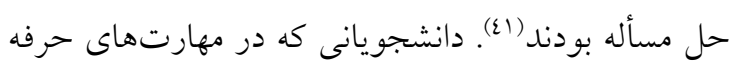

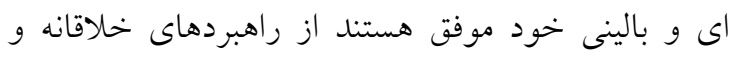
متفكر انهاى در برخورد با مشكلات استفاده مى كنند. معمولاً مهارتهاى حل مسأله و ميزان به كارگيرى آن در محيط

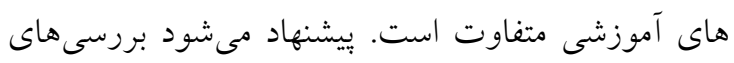

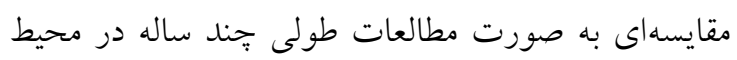

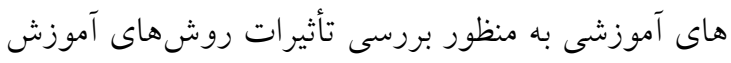

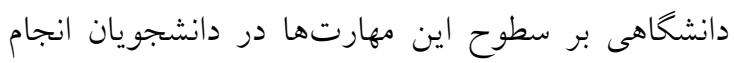

كردد. بر اساس بررسى هاى انجام شده در بزوهش حاضر، بيشتر

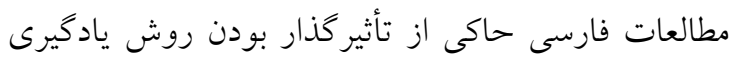

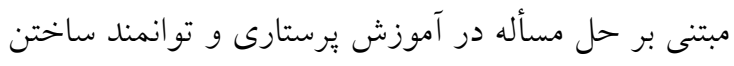

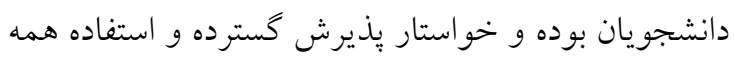


1. Scherpbier A, Hillen H. Lessons from problem-based learning: Oxford University Press, USA; 2010.

2. Gokhale AA. Collaborative Learning Enhances Critical Thinking. Encyclopedia of the sciences of learning. 2012:634-6.

3. Wong FK, Cheung S, Chung L, Chan K, Chan A, To T, et al. Framework for adopting a problembased learning approach in a simulated clinical setting. J Nurs Educ. 2008;47(11):508-14.

4. Haith-Cooper M. Problem-based learning within health professional education. What is the role of the lecturer? A review of the literature. Nurse education today. 2000;20(4):267-72.

5. Chunta KS, Katrancha ED. Using problem-based learning in staff development: strategies for teaching registered nurses and new graduate nurses. J Contin Educ Nurs. 2010;41(12):557-64.

6. Yuan H, Kunaviktikul W, Klunklin A, Williams BA. Improvement of nursing students' critical thinking skills through problem-based learning in the People's Republic of China: A quasiexperimental study. Nursing \& health sciences. 2008;10(1):70-6.

7. Albanese MA, Mitchell S. Problem-based learning: A review of literature on its outcomes and implementation issues. Academic medicine- Philadelphia 1993;68(1):52-81.

8. Day R, Salsali M. Problem based learning in collaborative pilot baccalaureate nursing programs: a project of the faculty of nursing Canada. Alberta University Press. 2000;15(4):22-5.

9. Klunklin A, Subpaiboongid P, Keitlertnapha P, Viseskul N, Turale S. Thai nursing students' adaption to problem-based learning: A qualitative study. Nurse education in practice. 2011;11(6):370-4.

10. Moattari M, Soltani A, Moosavinasab M. The effect of a short term course of problem solving on self-concept of nursing students at Shiraz faculty of nursing and midwifery. Iranian journal of medical education. 2005;5(2):147-55. [Persian]

11. Dadgari A, Dadvar L, Youssofi M. Application of Modified Problem Based- Learning (Mpbl) And students point of view. J Knowledge Health. 2008;3(2):19-25. [Persian]

12. Gwele N. The development of staff concerns during implementation of problem-based learning in a nursing programme [1]. Medical Teacher. 1997;19(4):275-84.

13. Landeen J, Jewiss T, Vajoczki S, Vine M. Exploring consistency within a problem-based learning context: perceptions of students and faculty. Nurse Education in Practice. 2013;13(4):277-82.

14. Ghezelghash A, Atashzadeh F, Alavi M, Yaghmai F. Comparing methods of lecturing, problem solving and self-learning via internet to learn proper interpretation of electrocardiogram among nursing student. Iran J Nurs Res. 2008;3(10-11):7-15. [Persian]

15. Hemmati Maslak Pak M, Orujlu S, Khalkhali H. The effect of problem-based learning training on nursing students' critical thinking skills. The Journal of Medical Education and Developmen. 2014;9(1):24-33. [Persian]

16. Fesharaki M, Islami M, Moghimian M, Azarbarzin M. The effect of lecture in comparison with lecture and problem based learning on nursing students self-efficacy in Najafabad Islamic Azad University. Iranian Journal of Medical Education. 2010;10(3):262-8. [Persian]

17. Asgari P. Comparison of problem solving and participatory teaching methods on clinical learning, anxiety and satisfaction of nursing students in Arak University of Medical Sciences. Journal of Nursing Education. 2019;7(1):41-50. [Persian]

18. Heidari M, Shahbazi S. he impact of training by social problem-solving model of D-zurilla \& gold fried on problem-solving skills of nursing students. Iran Journal of Nursing (IJN). 2012;25(76):19. [Persian]

19. Shahbazi S, Hazrati M, Moattari M, Heidari M. The Effect of Problem Solving Skills Training on Emotional Intelligence of Nursing Students of Shiraz (2008). Iranian Journal of Medical Education. 2012;12(1):67-76. [Persian]

20. Seyedfatemi N, Moshirabadi Z, Borimnejad L, Haghani H. Relationship between Problem Solving and Assertiveness Skills among Nursing Students. Hayat. 2013;19(3):70-81. [Persian]

21. Mortazavi E, Bagherpour M. The Effect of the Problem-Solving Education based on the Spirituality on the Philosophical Mindset and the Decision-Making Styles of the Nursing Students. Journal of Research in School and Virtual Learning. 2016;4(2):33-40. [Persian]

22. Porzoor P, Soleimani E. Relationship between nursess social problems solving ability and their empathy in intensive care units. Quarterly Journal of nursing management. 2015;3(4):26-35. [Persian] 
23. Namnabati M, Azar EF, Valizadeh S, Tazakori Z. Lecturing or Problem-based Learning: Comparing Effects of the Two Teaching Methods in Academic Achievement and Knowledge Retention in Pediatrics Course for Nursing Students. Iranian Journal of Medical Education. 2011;10(4):474-83. [Persian]

24. Shamsikhani S, Farmahini Farahani M, Shamsikhani S, Sobhani M. Effectiveness of problem solving training on depression in nursing student. Int J Palliat Nurs. 2014;2(1):63-71. [Persian]

25. Zamani N, Barahmand A, Farhadi M. The effects of problem-solving training in reducing anxiety among a group of nursing students. Journal of Nursing Education. 2017;6(3):56-61. [Persian]

26. Modanloo M, Khoddam H, Kolagaree S, Bastani F, Parvizi S, Abdollahi H. The Effect of problembased learning on nursing students' learning level. Strides in Development of Medical Education. 2010;7(1):17-25. [Persian]

27. Taheri R, Karimi F. The Relationship between Learning Styles and Problem-Solving Strategies in Undergraduate Nursing Students of Isfahan University of Medical Sciences, Iran. sdmej. 2017; 13(6):568-77. [Persian]

28. Aein F, Nourian K. Problem-based learning: a new experience in education of pediatric nursing course to nursing students. Journal of Shahrekord Uuniversity of Medical Sciences. 2006;8(2):1620. [Persian]

29. Mousaai Fard M, Amini K. Comparison of two teaching methods (Lecturing and PBL) from the point of Zanjan Medical University Nursing Student View. Journal of Medical Education Development. 2010;2(3):60-8. [Persian]

30. Penjvini S, Shahsavari S. Comparison of the effects of conventional and PBL teaching methods on nursing students' skills in administrating medication to children in Sanandaj. SJKU. 2007;12(3):7381. [Persian]

31. Pishgooie Ah, Atashzadeh shurideh F, Barbaz A, Zareiyan A. Comparison of Three Instructional Methods for Drug Calculation Skill in Nursing Critical Care Courses: Lecturing, Problem Solving, and Computer-Assisted Self-Learning. Iranian Journal of Medical Education. 2012;12(6):420-9. [Persian]

32. Momeni H, Salehi A, Sadeghi H. Comparing the Effect of Problem Based Learning and Concept Mapping on Critical Thinking Disposition of Nursing Student. Bimonthly of Education Strategies in Medical Sciences. 2017;10(4):234-44. [Persian]

33. Aien F, Del Aram M. The Effect of Problem-based Learning Solving on the Development of Critical Thinking Skills in Nursing Students. Iranian Journal of Medical Education. 2005;5(14):5160. [Persian]

34. Shahsavari IS. Designing and Implementing the Integrated Learning Program in Nursing Education: the Integration of Problem-Based Learning and Role Playing Methods in Teaching the Practical Part of Patient Education.. Teb Va Tazkiyeh. 2017;3(26):219-27. [Persian]

35. Rasouli M, Rasouli A, Kalhor N. Comparing Lecture and Problem-based Learning Methods in Teaching Gastrointestinal Part of Patients' Health Assessment on Nursing Students' Knowledge and Their Performance. Journal of Nursing Education. 2017;6(5):25-31. [Persian]

36. Mojgan baghaee lakeh ZAkR. A Comparision of two Teaching Strategies : Lecture and PBL, on Learning and Retaining in Nursing Students. Journal of Guilan University of Medical Sciences. 2003;12(47):86-94. [Persian]

37. Nohi E. Investigating the Success and Suppression Factors Problem Based Learning from the Point of View of the Students of MSc in Nursing. Iranian journal of medical education. 2005;5(14):6571. [Persian]

38. Abolhasani S, Haghani F. Problem-based Learning in Nursing Education: A Review Article. Iranian Journal of Medical Education. 2011;10(5):726-34. [Persian]

39. Noohi E, Abbaszadeh A, Sayed Bagher Madah S, Borhani F. Collaborative learning experiences in problem-based learning (PBL) education: a qualitative study. Journal of Qualitative Research in Health Sciences. 2013;1(4):255-67. [Persian]

40. Abedini Z, Akhondizadeh K, Ahmari T H. Nursing Students' Experiences of the Modified Problembased Learning (MPBL) and Small Group Work. Journal Of Sabzevar University Of Medical Sciences. 2010;17(3):180-8. [Persian] 
41. Feizi Konjini L, Fadakar Soghe R, Chehrzad M, Kazemnejad-Leili E. Problem Solving Skills and their Related Factors in Nursing Students. Journal of Holistic Nursing And Midwifery. 2016;26(3):86-95.[Persian] 